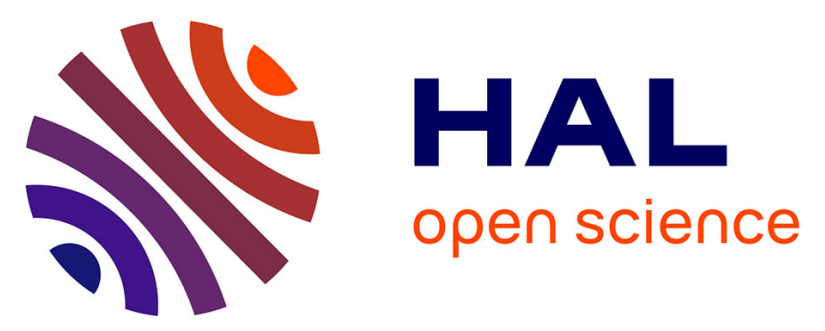

\title{
Synthesis, docking and evaluation of in vitro anti-inflammatory activity of novel morpholine capped $\beta$-lactam derivatives
}

Roghayeh Heiran, Saghi Sepehri, Aliasghar Jarrahpour, Carole Digiorgio, Hana Douafer, Jean Michel Brunel, Ahmad Gholami, Elham Riazimontazer, Edward Turos

\section{To cite this version:}

Roghayeh Heiran, Saghi Sepehri, Aliasghar Jarrahpour, Carole Digiorgio, Hana Douafer, et al.. Synthesis, docking and evaluation of in vitro anti-inflammatory activity of novel morpholine capped $\beta$-lactam derivatives. Bioorganic Chemistry, 2020, 102, pp.104091. 10.1016/j.bioorg.2020.104091 . hal-03085012

\section{HAL Id: hal-03085012 https://hal.science/hal-03085012}

Submitted on 12 Jan 2021

HAL is a multi-disciplinary open access archive for the deposit and dissemination of scientific research documents, whether they are published or not. The documents may come from teaching and research institutions in France or abroad, or from public or private research centers.
L'archive ouverte pluridisciplinaire HAL, est destinée au dépôt et à la diffusion de documents scientifiques de niveau recherche, publiés ou non, émanant des établissements d'enseignement et de recherche français ou étrangers, des laboratoires publics ou privés. 


\title{
Synthesis, docking and evaluation of in vitro anti-inflammatory activity of novel morpholine capped $\beta$-lactam derivatives
}

\author{
Roghayeh Heiran, ${ }^{\text {a,b }}$ Saghi Sepehri, ${ }^{c}$ Aliasghar Jarrahpour,,${ }^{a}$, Carole Digiorgio, ${ }^{d}$ Hana \\ Douafer, ${ }^{\mathrm{e}}$ Jean Michel Brunel, ${ }^{\mathrm{e}}$ Ahmad Gholami, ${ }^{\mathrm{a}}$ Elham Riazimontazer ${ }^{\mathrm{a}}$ and Edward \\ $\operatorname{Turos}^{\mathbf{f}}$ \\ ${ }^{a}$ Department of Chemistry, College of Sciences, Shiraz University, 71454 Shiraz, Iran \\ ${ }^{\mathrm{b}}$ Department of Chemistry, Estahban Higher Education Center, Estahban, Iran \\ ${ }^{c}$ Department of Medicinal Chemistry, School of Pharmacy, Ardabil University of Medical \\ Sciences, Ardabil, Iran \\ d Aix Marseille Université, CNRS, IRD, IMBE UMR 7263, Laboratoire de Mutagénèse \\ Environnementale, 13385 Marseille, France \\ e Aix Marseille Université, INSERM, SSA, MCT, Marseille, France \\ ${ }^{\mathrm{f}}$ Center for Molecular Diversity in Drug Design, Discovery, and Delivery, Department of \\ Chemistry, CHE 205, 4202 East Fowler Avenue, University of South Florida, Tampa, Florida, \\ 33620 USA
}

E-mail: jarahpor@shirazu.ac.ir, aliasghar6683@yahoo.com

\begin{abstract}
:
This study reports the synthesis and biological investigation of three series of novel $\beta$-lactams bearing a morpholine substituent of the nitrogen center. These products were synthesized via Staudinger's [2+2]-ketene-imine cycloaddition reaction. The cycloadducts were fully characterized by spectral data, including ${ }^{1} \mathrm{H}-\mathrm{NMR},{ }^{13} \mathrm{C}-\mathrm{NMR}$, IR, mass spectroscopy and elemental analyses, and then evaluated for anti-inflammatory activity. A number of the derivatives demonstrated higher therapeutic ratios than dexamethasone and corticosteroid medication. In silico molecular docking experiments showed a good correlation between the experimental activity and the calculated binding affinity to human inducible nitric oxide synthase, the enzymatic target for the anti-inflammatory response.
\end{abstract}

Keywords: 2-azetidinone, Staudinger reactions, morpholine, anti-inflammatory, NOS, In silico 


\section{Introduction:}

Inflammation is one of the most important defenses of the body against tissue damage or infection. However, chronic inflammation may lead to disease, such as arthritis, atherosclerosis, psoriasis, cancer, infections, asthma, etc. [1,2] Therefore, treatment of inflammation is a high priority topic for researchers over the past decades. [3] Inflammation as a biological signal of the immune system can be caused by different factors such as pathogens, damaged cells and toxic compounds. [4] Abnormal activation of certain enzymes such as inducible nitric oxide synthase (iNOS) [5] is one reason for inflammation-related disease and inhibitation of iNOS may exert anti-inflammatory effects. [6] Therefore, development of anti-inflammatory chemicals is still of great importance.

$\beta$-Lactams are among the most important classes of organic compounds in the last century due to their diverse biological activities, $[7,8]$ including their well-known antibacterial properties, as well as cholesterol absorption inhibition, [9,10] cysteine protease inhibition, [11] tryptase and chymase inhibition, [12] and anticancer, [13,14] antifungal, [15,16] antimalarials, [17,18] antiHIV, [19] antidiabetic, [20] antioxidant, [21] and anti-inflammatory activities. [22,23] Kumar et.al. synthesized a series of quinazolinone $\beta$-lactam conjugates and investigated their antiinflammatory activities. [22] Recently, our laboratories have prepared chromeno $\beta$-lactam hybrids and have examined their anti-inflammatory properties. [23]

Another class of nitrogen ring compounds are the morpholine derivatives, often used as the building blocks, [24] selective norepinephrine reuptake inhibitors [25] and dopamine D4 receptor ligands. [26] Moreover, they have been shown anti-inflammatory, [27,28] antiparasitic, [29] antimicrobial, [30,31] antitumor, [32] and antioxidant activities. [33,34] Linezolid is an example of a commercially important antibacterial agent possessing a morpholine ring (Scheme 1). [35] Recently, Cebeci et.al. have reported $\beta$-lactam derivatives containing a morpholine moiety (Scheme 1) that possess antimicrobial, antioxidant, antitubercular, and antiurease activities, as well as acetylcholinesterase inhibitory properties. [36]

Our interest in new structural variants of biologically active $\beta$-lactams has led us to study hybridized systems, wherein the $\beta$-lactam core is combined with other relevant heterocycles. In this current study, we detail our studies on the synthesis and anti-inflammatory properties of $\beta$ lactam-morpholine hybrids. 


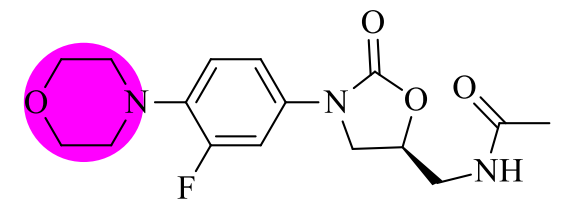

(a)

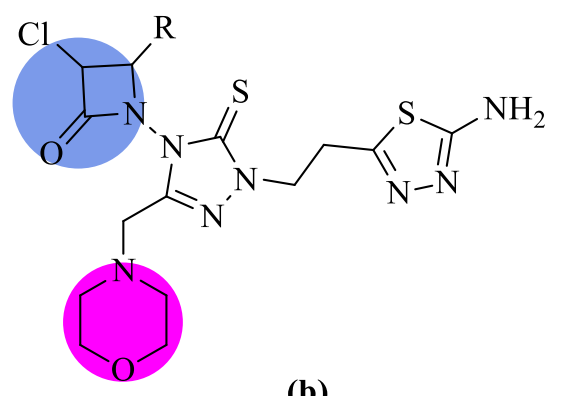

(b)

Scheme 1. Structures of (a) linezolid and (b) $\beta$-lactam derivatives bearing a morpholine ring [36]

\section{Results and discussion}

\section{Chemistry}

Morpholine-substituted $\beta$-lactams 3a-o were synthesized by the $[2+2]$-imine-ketene cycloaddition (Staudinger reaction) of N-morpholinohydrazones $\mathbf{1}$ with ketene precursors $\mathbf{2}$ and $\mathbf{2}^{\prime}$ in the presence of $p$-toluenesulfonyl chloride and triethylamine in anhydrous dichloromethane (Scheme 2; Table 1).

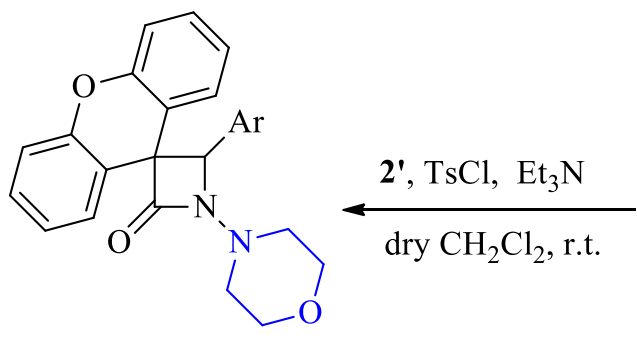

30

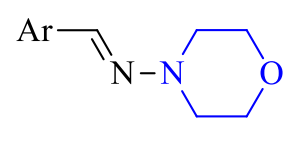

1
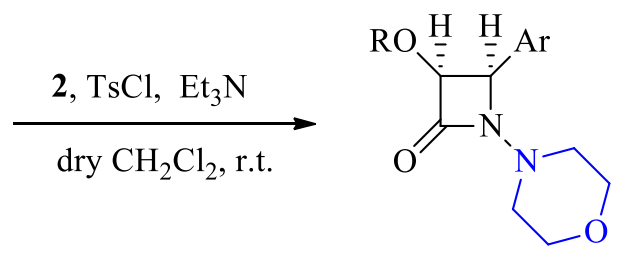

3a-n

$$
2=\mathrm{ROCH}_{2} \mathrm{CO}_{2} \mathrm{H}
$$

$\mathbf{2}^{\prime}=9 H$-xanthene-9-carboxylic acid

$\mathbf{A r}=2-\mathrm{NO}_{2} \mathrm{C}_{6} \mathrm{H}_{4}, 3-\mathrm{NO}_{2} \mathrm{C}_{6} \mathrm{H}_{4}, 4-\mathrm{NO}_{2} \mathrm{C}_{6} \mathrm{H}_{4}, 4-\mathrm{CNC}_{6} \mathrm{H}_{4}$

$\mathbf{R}=\mathrm{C}_{6} \mathrm{H}_{5}, 4-\mathrm{ClC}_{6} \mathrm{H}_{4}$, Naphthyl, $\mathrm{CH}_{3}$

Scheme 2. General synthetic pathway for the synthesis of $\beta$-lactams 3a-o

These resulting $\beta$-lactam adducts were purified by silica gel chromatography, then structurally characterized by spectral and elemental analyses. It is noteworthy that all the $\beta$-lactams 3a-n possess the cis relative configuration as determined from the observed coupling constants of 
the $\mathrm{H}-3$ and $\mathrm{H}-4$ protons of the $\beta$-lactam ring $(J=4.6-5.1 \mathrm{~Hz})$ in the ${ }^{1} \mathrm{H}-\mathrm{NMR}$ spectra. Spiro- $\beta$ lactam 3o showed a single peak at $5.38 \mathrm{~Hz}$ for the sole $\beta$-lactam ring hydrogen. X-ray crystallographic analysis of $\mathbf{3 0}$ [37] revealed that the $\beta$-lactam ring is nearly planar and the morpholine ring adopts a chair conformation (Fig. 1).

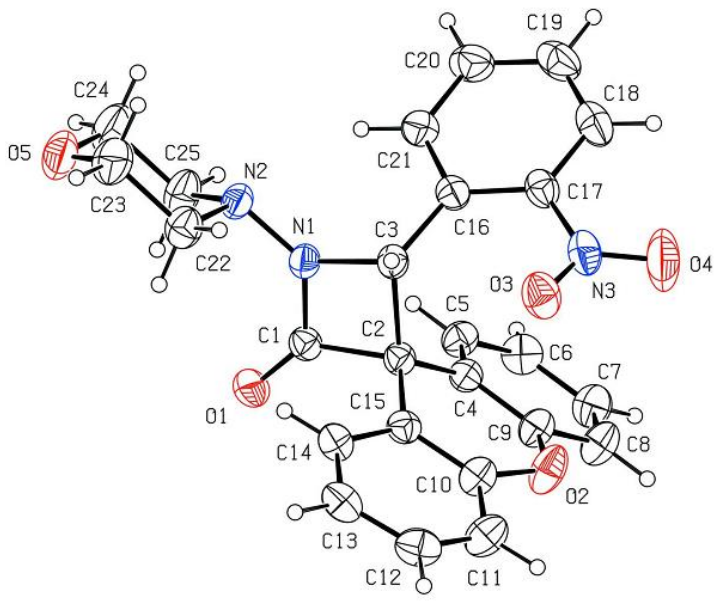

Fig. 1. X-Ray structure analysis of compound $\mathbf{3 o}$.

Table 1. Isolated yield of monocyclic $\beta$-lactams 3a-o.

\begin{tabular}{cccccccc}
\hline Entry & $\mathbf{A r}$ & $\mathbf{R}$ & yield (\%) & Entry & $\mathbf{A r}$ & $\mathbf{R}$ & yield (\%) \\
\hline 3a & $4-\mathrm{NO}_{2} \mathrm{C}_{6} \mathrm{H}_{4}$ & $\mathrm{C}_{6} \mathrm{H}_{5}$ & 32 & $\mathbf{3 i}$ & $2-\mathrm{NO}_{2} \mathrm{C}_{6} \mathrm{H}_{4}$ & Naphthyl & 38 \\
\hline 3b & $4-\mathrm{NO}_{2} \mathrm{C}_{6} \mathrm{H}_{4}$ & $4-\mathrm{ClC}_{6} \mathrm{H}_{4}$ & 35 & $\mathbf{3 j}$ & $2-\mathrm{NO}_{2} \mathrm{C}_{6} \mathrm{H}_{4}$ & $\mathrm{CH}_{3}$ & 64 \\
\hline $\mathbf{3 c}$ & $4-\mathrm{NO}_{2} \mathrm{C}_{6} \mathrm{H}_{4}$ & Naphthyl & 38 & $\mathbf{3 k}$ & $4-\mathrm{CNC}_{6} \mathrm{H}_{4}$ & $\mathrm{C}_{6} \mathrm{H}_{5}$ & 35 \\
\hline 3d & $4-\mathrm{NO}_{2} \mathrm{C}_{6} \mathrm{H}_{4}$ & $\mathrm{CH}_{3}$ & 45 & $\mathbf{3 l}$ & $4-\mathrm{CNC}_{6} \mathrm{H}_{4}$ & $4-\mathrm{ClC}_{6} \mathrm{H}_{4}$ & 29 \\
\hline 3e & $3-\mathrm{NO}_{2} \mathrm{C}_{6} \mathrm{H}_{4}$ & $\mathrm{C}_{6} \mathrm{H}_{5}$ & 25 & $\mathbf{3 m}$ & $4-\mathrm{CNC}_{6} \mathrm{H}_{4}$ & Naphthyl & 49 \\
\hline 3f & $3-\mathrm{NO}_{2} \mathrm{C}_{6} \mathrm{H}_{4}$ & $\mathrm{CH}_{3}$ & 43 & $\mathbf{3 n}$ & $4-\mathrm{CNC}_{6} \mathrm{H}_{4}$ & $\mathrm{CH}_{3}$ & 36 \\
\hline 3g & $2-\mathrm{NO}_{2} \mathrm{C}_{6} \mathrm{H}_{4}$ & $\mathrm{C}_{6} \mathrm{H}_{5}$ & 36 & $\mathbf{3 o}$ & $2-\mathrm{NO}_{2} \mathrm{C}_{6} \mathrm{H}_{4}$ & - & 41 \\
\hline 3h & $2-\mathrm{NO}_{2} \mathrm{C}_{6} \mathrm{H}_{4}$ & $4-\mathrm{ClC}_{6} \mathrm{H}_{4}$ & 23 & & & & \\
\hline
\end{tabular}

In an earlier paper of our research group morpholine $\beta$-lactams conjugates linked via propyl reported as antifungal agents. [38] Therefore, to investigate the influence of propyl linkage between $\beta$-lactam and morpholine rings, $\beta$-lactams $5 \mathbf{a}-\mathbf{h}$ were synthesized via Staudinger reactions of the corresponding imines 4 with different substituted acetic acids $\mathbf{2}$ or 2 ' in the presence of $p$ toluenesulfonyl chloride and trimethylamine. Isolated product yields were moderate to good (Scheme 3; Table 2). All the products were characterized by spectral and elemental analyses. The 
cis stereochemistry of monocyclic $\beta$-lactams $\mathbf{5 a}-\mathbf{f}$ was deduced from the analysis of their ${ }^{1} \mathrm{H}-\mathrm{NMR}$ spectra. The spiro- $\beta$-lactams $\mathbf{5 g}$ and $\mathbf{5 h}$ showed a single peak for $\mathrm{H}-4$ at 4.73 and $4.72 \mathrm{~Hz}$, respectively. The X-ray crystallographic structures of $\mathbf{5 f}$ [39] and $\mathbf{5 h}$ [40] revealed a chair conformation for the morpholine ring and a nearly planar $\beta$-lactam ring in $\mathbf{5 h}$ (Fig. 2). The aryl nitro substituent in compounds $\mathbf{5 a - f}$ could be selectively reduced with Raney nickel and aqueous hydrazine to give aminoaryl $\beta$-lactams 6a-f (Table 2). The cis ring stereochemistry of $\mathbf{6 a - f}$ was confirmed by ${ }^{1} \mathrm{H}-\mathrm{NMR}$ spectroscopy.

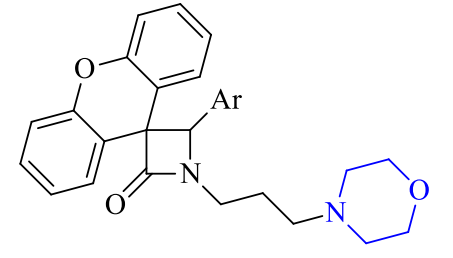

5g-h

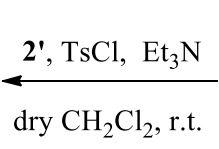

dry $\mathrm{CH}_{2} \mathrm{Cl}_{2}$, r.t.

$2=\mathrm{ROCH}_{2} \mathrm{CO}_{2} \mathrm{H}$

$\mathbf{2}^{\prime}=9 H$-xanthene-9-carboxylic acid

$\mathbf{A r}=3-\mathrm{NO}_{2} \mathrm{C}_{6} \mathrm{H}_{4}, 4-\mathrm{NO}_{2} \mathrm{C}_{6} \mathrm{H}_{4}$

Ar' $=3-\mathrm{NH}_{2} \mathrm{C}_{6} \mathrm{H}_{4}, 4-\mathrm{NH}_{2} \mathrm{C}_{6} \mathrm{H}_{4}$

$\mathbf{R}=\mathrm{C}_{6} \mathrm{H}_{5}, 4-\mathrm{ClC}_{6} \mathrm{H}_{4}, 2,4-\mathrm{Cl}_{2} \mathrm{C}_{6} \mathrm{H}_{3}$, Naphthyl

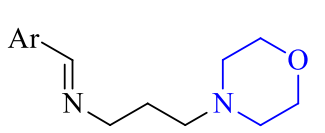

4

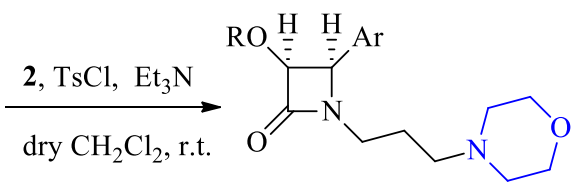

5a-f

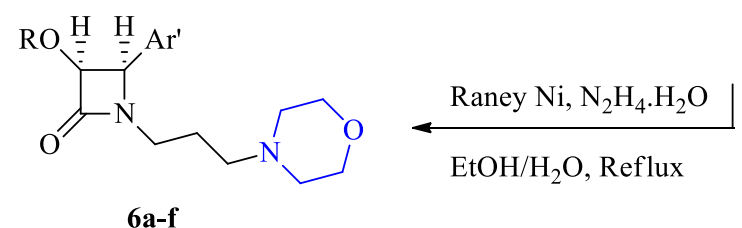

6a-f

Scheme 3. General synthetic pathway for the synthesis of $\beta$-lactams $\mathbf{5 a - h}$ and $\mathbf{6 a - f}$.

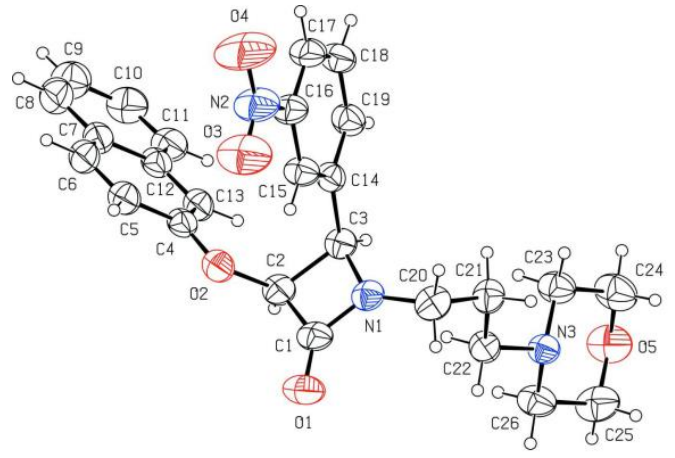

$\mathbf{5 f}$

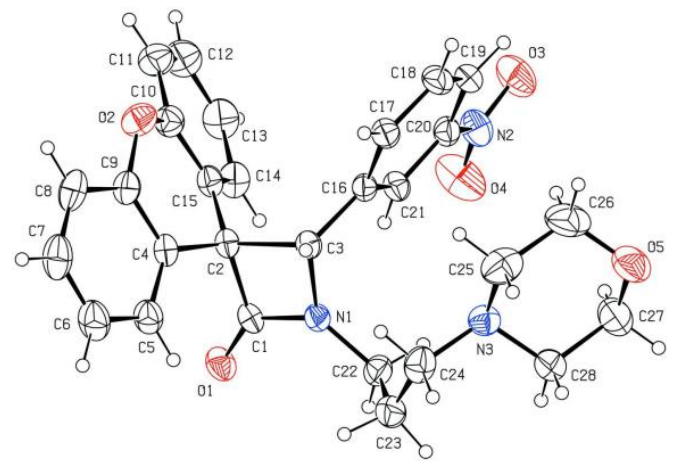

$5 \mathbf{h}$

Fig. 2. X-ray crystal structures of compounds $\mathbf{5 f}$ and $\mathbf{5 h}$.

Table 2. Isolated yield of monocyclic $\beta$-lactams 5a-h and 6a-f. 


\begin{tabular}{cccccccc}
\hline Entry & $\mathbf{A r}$ & $\mathbf{R}$ & yield (\%) & Entry & $\mathbf{A r}$ & $\mathbf{R}$ & yield (\%) \\
\hline $\mathbf{5 a}$ & $4-\mathrm{NO}_{2} \mathrm{C}_{6} \mathrm{H}_{4}$ & $\mathrm{C}_{6} \mathrm{H}_{5}$ & 76 & $\mathbf{5 h}$ & $3-\mathrm{NO}_{2} \mathrm{C}_{6} \mathrm{H}_{4}$ & - & 59 \\
\hline $\mathbf{5 b}$ & $4-\mathrm{NO}_{2} \mathrm{C}_{6} \mathrm{H}_{4}$ & $4-\mathrm{ClC}_{6} \mathrm{H}_{4}$ & 74 & $\mathbf{6 a}$ & $4-\mathrm{NH}_{2} \mathrm{C}_{6} \mathrm{H}_{4}$ & $\mathrm{C}_{6} \mathrm{H}_{5}$ & 96 \\
\hline $\mathbf{5 c}$ & $4-\mathrm{NO}_{2} \mathrm{C}_{6} \mathrm{H}_{4}$ & $2,4-\mathrm{Cl}_{2} \mathrm{C}_{6} \mathrm{H}_{3}$ & 63 & $\mathbf{6 b}$ & $4-\mathrm{NH}_{2} \mathrm{C}_{6} \mathrm{H}_{4}$ & $4-\mathrm{ClC}_{6} \mathrm{H}_{4}$ & 92 \\
\hline $\mathbf{5 d}$ & $4-\mathrm{NO}_{2} \mathrm{C}_{6} \mathrm{H}_{4}$ & $\mathrm{Naphthyl}$ & 79 & $\mathbf{6 c}$ & $4-\mathrm{NH}_{2} \mathrm{C}_{6} \mathrm{H}_{4}$ & $2,4-\mathrm{Cl}_{2} \mathrm{C}_{6} \mathrm{H}_{3}$ & 67 \\
\hline $\mathbf{5 e ^ { \mathrm { a } }}$ & $3-\mathrm{NO}_{2} \mathrm{C}_{6} \mathrm{H}_{4}$ & $\mathrm{C}_{6} \mathrm{H}_{5}$ & 63 & $\mathbf{6 d}$ & $4-\mathrm{NH}_{2} \mathrm{C}_{6} \mathrm{H}_{4}$ & Naphthyl & 79 \\
\hline $\mathbf{5 f}$ & $3-\mathrm{NO}_{2} \mathrm{C}_{6} \mathrm{H}_{4}$ & $\mathrm{Naphthyl}$ & 63 & $\mathbf{6 e}$ & $3-\mathrm{NH}_{2} \mathrm{C}_{6} \mathrm{H}_{4}$ & $\mathrm{C}_{6} \mathrm{H}_{5}$ & 68 \\
\hline $\mathbf{5 g}$ & $4-\mathrm{NO}_{2} \mathrm{C}_{6} \mathrm{H}_{4}$ & - & 71 & $\mathbf{6 f}$ & $3-\mathrm{NH}_{2} \mathrm{C}_{6} \mathrm{H}_{4}$ & Naphthyl & 59 \\
\hline
\end{tabular}

${ }^{\mathrm{a}}$ previously reported synthesis [38]

\section{Anti-Inflammatory Assay}

Our interest in these morpholine- $\beta$-lactam hybrids was with respect to possible antiinflammatory activity, a program our laboratories initiated recently. Anti-inflammatory activity was evaluated through the inhibition of nitric oxide production by LPS-stimulated mouse macrophages. Nitric oxide (NO) is a short-lived molecule, which is released from a variety of cells in response to different pathologic stimuli. NO exerts modulatory activity under a variety of inflammatory conditions, and may act as a vasodilator and a platelet inhibitor, and prevent neutrophil adhesion. As such, NO plays a protective role during infections and other stresses to the immune system.

In the anti-inflammatory assay, inflammation reactions are induced by a simulated microbial infection in macrophage cultures. In response to the microbial infection, a strong production of NO is achieved by macrophages in the culture medium. The anti-inflammatory activity is based on the capacity of compounds to inhibit inflammation reactions, and then NO release in the culture medium. The anti-inflammatory potential in evaluated by calculating, for each compound, the ratio between the anti-inflammatory activity and the cytotoxicity.

Results of the anti-inflammatory assays are reported in Table 3. Nine compounds, namely 3c, 3h, 3k, 3o, 5c, 5d, 5f, 6d, and 6f, presented excellent IC $_{50}$ values for NO release, similar or better than the dexamethasone corticosteroid medication. The $\mathrm{IC}_{50}$ values for cell viability were also measured, in order to determine anti-inflammatory ratios. From this, we observed that morpholine- $\beta$-lactams $3 \mathbf{e}, \mathbf{3 h}, \mathbf{3 k}, \mathbf{5 c}, \mathbf{5 f}, \mathbf{6 c}, \mathbf{6 d}$, and $\mathbf{6 f}$ afford improved anti-inflammatory ratios to that of dexamethasone. Inspection of compounds $5 \mathbf{c}, 5 \mathbf{5 d}, \mathbf{5 f}, \mathbf{6 c}, \mathbf{6 d}$, and $\mathbf{6 f}$ indicates that the phenyl ring substituent $\left(\mathrm{NO}_{2}\right.$ versus $\left.\mathrm{NH}_{2}\right)$ plays an important role on anti-inflammatory activities. 
For instance, $\mathbf{6} \mathbf{f}$ bearing an $\mathrm{NH}_{2}$ at the meta position provides a better anti-inflammatory ratio (99\%) compared to its para isomer $\mathbf{6 d}(55 \%)$.

Table 3. Anti-inflammatory activity of derivatives 3a-o, 5a-h, and 6a-f.

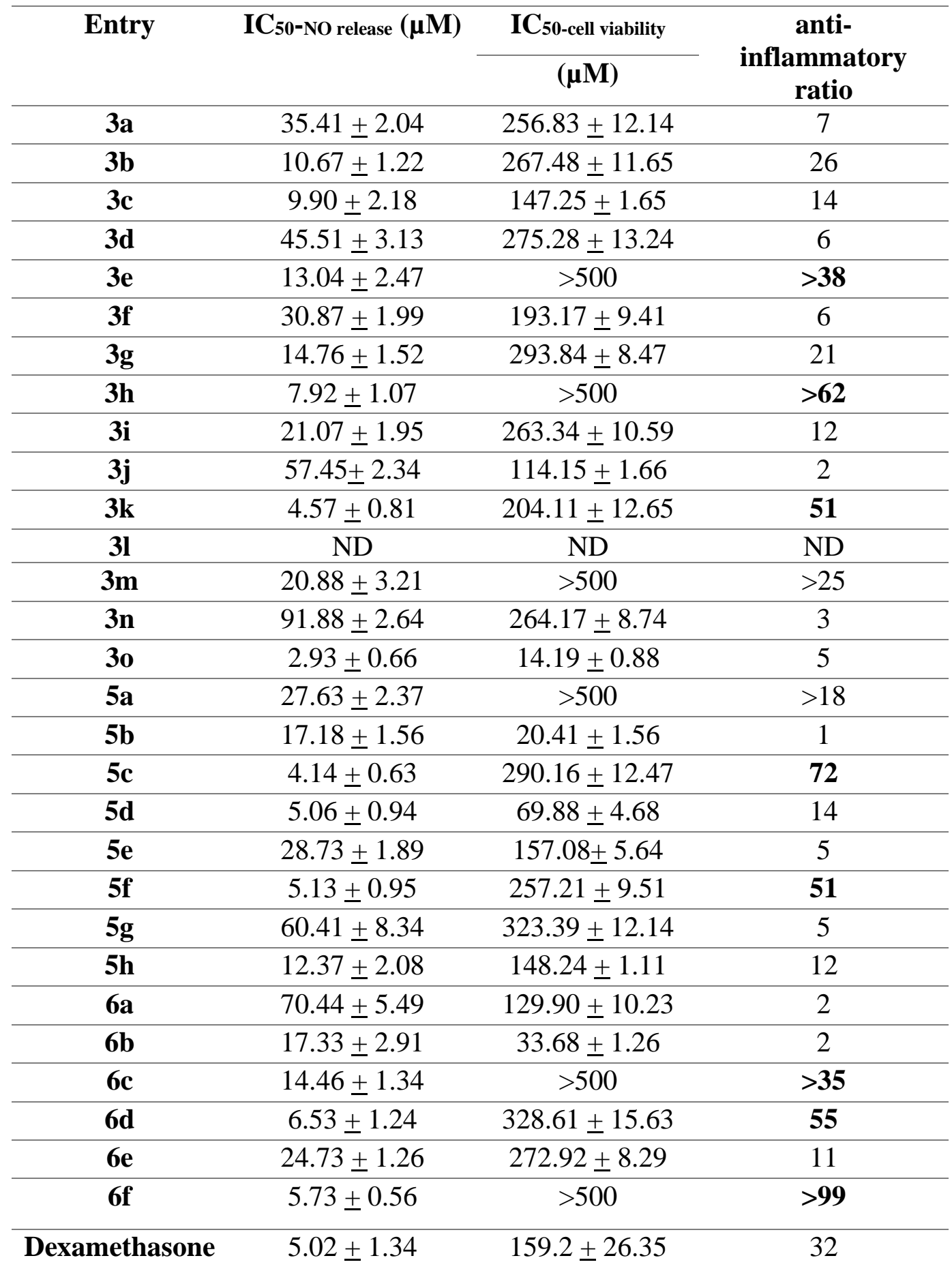

ND: Not determined due to insolubility in the media 


\section{Molecular Docking of the $\beta$-Lactams to the Human Nitric Oxide Synthase}

Molecular docking studies were next performed to try to understand and further validate the anti-inflammatory activities, and to explore plausible binding interactions with the enzymatic pocket of the human inducible nitric oxide synthase protein. [41] The X-ray crystallographic structure of human inducible nitric oxide synthase (PDB ID: 4NOS) was selected as the docking template. The procedure was carried out by eliminating the structure of the co-crystallized ligand and redocking individual $\beta$-lactams (3a-o, 5a-h or 6a-f) into this region. Root-mean-square deviation (RMSD) of the Cartesian coordinates of the atoms of the ligand in the docked and crystallographic conformations is the principle of the docking validation (RMSD $2 \AA$ ). Validation of molecular docking showed RMSD value was for PDB ID: 4NOS = $0.4 \AA$. [23] The scores of docking results based on the free binding energies and the hydrophobic and hydrogen bond interactions involved in the binding mode are presented in Table 4.

Table 4. Results of computational docking of morpholine-substituted $\beta$-lactams 3a-o, 5a-h and 6a-f into the active site of human inducible nitric oxide synthase (PDB ID: 4NOS)

\begin{tabular}{|c|c|c|c|c|c|}
\hline Code & $\begin{array}{l}\Delta G_{\text {binding }} \\
\text { (Kcal/mol) }\end{array}$ & Hydrogen bond & Hydrophobic interaction & $\pi-\pi$ & Cation- $\pi$ \\
\hline 3a & -8.97 & Tyr373, Gln263 & $\begin{array}{l}\text { Asp382, Tyr347, Trp346, } \\
\text { Val352, Pro350, Glu377, } \\
\text { Ala262, Ala351, Asn354, } \\
\text { Met355 }\end{array}$ & Hem & - \\
\hline 3b & -9.74 & - & $\begin{array}{l}\text { Gly371, Val352, Ala262, } \\
\text { Pro350, Ala351, Asn370, } \\
\text { Glu377, Gln263, Tyr373, } \\
\text { Asp382 }\end{array}$ & - & - \\
\hline $3 c$ & -10.20 & - & $\begin{array}{l}\text { Asp382, Tyr373, Glu377, } \\
\text { Val352, Gln263, Met355, } \\
\text { Ala262, Pro350, Ala351, } \\
\text { Phe369, Asn354, Tyr491 }\end{array}$ & - & - \\
\hline 3d & -8.77 & Met480 & $\begin{array}{l}\text { Trp461, Glu479, Ile462, } \\
\text { Cys115, Gly117, Cys110 }\end{array}$ & - & $\mathrm{Zn}$ \\
\hline $3 e$ & -9.34 & Met480 & $\begin{array}{l}\text { Ser118, Asn482, Ile462, } \\
\text { Cys110, Cys 115, Gly117, } \\
\text { Trp461, Glu479 }\end{array}$ & - & $\mathrm{Zn}$ \\
\hline 3f & -9.04 & Met 480 & $\begin{array}{l}\text { Trp461, Glu479, Ile462, } \\
\text { Asp460, Asn482, Cys115, } \\
\text { Gly117, Cys110 }\end{array}$ & - & $\mathrm{Zn}$ \\
\hline
\end{tabular}




\begin{tabular}{|c|c|c|c|c|c|}
\hline $3 g$ & -8.36 & - & $\begin{array}{l}\text { Ile462, Gly117, Cys115, } \\
\text { Asp460, Asn482, Cys110, } \\
\text { Ser118, Met480, Glu479, } \\
\text { Trp461 }\end{array}$ & - & $\mathrm{Zn}$ \\
\hline $3 h$ & -8.35 & - & $\begin{array}{l}\text { Cys110, Trp461, Cys115, } \\
\text { Ile462, Ser118, Gly117, } \\
\text { Asp460, Asn482 }\end{array}$ & - & $\mathrm{Zn}$ \\
\hline $3 \mathbf{i}$ & -10.34 & - & $\begin{array}{l}\text { Asp460, Asn482, Gly117, } \\
\text { Ile462, Cys115, Ser118, } \\
\text { Cys110, Met480, Phe476, } \\
\text { Glu479, Trp461, Gln478 }\end{array}$ & Trp461 & $\mathrm{Zn}$ \\
\hline $\mathbf{3 j}$ & -7.49 & - & $\begin{array}{l}\text { Trp461, Ile462, Met480, } \\
\text { Asn482, Cys115, Cys110, } \\
\text { Gly117 }\end{array}$ & - & $\mathrm{Zn}$ \\
\hline $3 \mathbf{k}$ & -8.16 & Tyr347 & $\begin{array}{l}\text { Met355, Val352, Asn370, } \\
\text { Gln263, Ala351, Glu377, } \\
\text { Pro350, Tyr373, Asp382 }\end{array}$ & Hem & - \\
\hline 31 & -8.48 & Tyr373 & $\begin{array}{l}\text { Glu377, Asp382, Arg381, } \\
\text { Gln263, Val352, Ala351, } \\
\text { Pro350 }\end{array}$ & - & - \\
\hline $3 m$ & -9.56 & Tyr373 & $\begin{array}{l}\text { Arg381, Asp382, Glu377, } \\
\text { Gln263, Pro350, Ala351, } \\
\text { Val352, Gly371, Asn370, } \\
\text { Phe369 }\end{array}$ & - & - \\
\hline $3 n$ & -6.79 & Gln263 & $\begin{array}{l}\text { Phe369, Gly371, Asn370, } \\
\text { Ala351, Tyr373, Pro350, } \\
\text { Val352, Glu377, Tyr347, }\end{array}$ & - & - \\
\hline 30 & -8.25 & - & $\begin{array}{l}\text { Ile462, Met480, Trp461, } \\
\text { Asn482, Ala459, Asp460, } \\
\text { Gly117, Ser118, Cys115 }\end{array}$ & Trp461 & - \\
\hline $5 a$ & -9.85 & - & $\begin{array}{l}\text { Phe369, Asn354, Ala262, } \\
\text { Ala351, Val352, Gln263, } \\
\text { Pro350, Glu377, Tyr373, } \\
\text { Asp382, Arg388, Arg381 }\end{array}$ & - & - \\
\hline $5 b$ & -10.62 & - & $\begin{array}{l}\text { Arg388, Asp382, Arg381, } \\
\text { Ala351, Phe369, Glu377, } \\
\text { Tyr373, Gln263, Ala262, } \\
\text { Val352, Pro350 }\end{array}$ & Hem & - \\
\hline $5 c$ & -10.74 & Gln263 & $\begin{array}{l}\text { Gly371, Asn370, Pro350, } \\
\text { Val352, Tyr373, Ala351, } \\
\text { Ala262, Arg388, Asn354, } \\
\text { Glu377, Arg381, Asp382 }\end{array}$ & - & - \\
\hline $5 d$ & -8.04 & Tyr373 & $\begin{array}{l}\text { Asn370, Ala351, Phe } 369 \text {, } \\
\text { Pro350, Val352, Gly371, } \\
\text { Met355, Ala262, Glu377, }\end{array}$ & Hem & - \\
\hline
\end{tabular}




\begin{tabular}{|c|c|c|c|c|c|}
\hline & & & $\begin{array}{l}\text { Gln263, Asp382, Arg381, } \\
\text { Arg388 }\end{array}$ & & \\
\hline $5 e$ & -9.55 & Gln263 & $\begin{array}{l}\text { Asn370, Gly371, Phe369, } \\
\text { Tyr373, Ala351, Pro350, } \\
\text { Asp382, Arg388, Glu377, } \\
\text { Arg381 }\end{array}$ & - & - \\
\hline $5 f$ & -10.58 & Gln263 & $\begin{array}{l}\text { Arg388, Arg381, Asp382, } \\
\text { Pro350, Glu377, Tyr373, } \\
\text { Met355, Phe369, Val352, } \\
\text { Asn354, Tyr491, Ala262, } \\
\text { Asn370 }\end{array}$ & - & - \\
\hline $5 g$ & -8.44 & Gln263 & $\begin{array}{l}\text { Arg388, Glu377, Asp382, } \\
\text { Arg381, Ala262, Ala351, } \\
\text { Val352, Phe369 }\end{array}$ & - & - \\
\hline $5 \mathrm{~h}$ & -8.23 & - & $\begin{array}{l}\text { Gly117, Cys110, Cys115, } \\
\text { Trp461, Met } 480\end{array}$ & - & $\mathrm{Zn}$ \\
\hline $6 a$ & -8.51 & Asp382, Asn354 & $\begin{array}{l}\text { Tyr373, Pro350, Gly371, } \\
\text { Trp372, Glu377, Val352, } \\
\text { Tyr491, Ala262 }\end{array}$ & Hem & - \\
\hline 6b & -7.55 & Gln263 & $\begin{array}{l}\text { Asp382, Arg381, Glu377, } \\
\text { Arg388, Tyr373, Asn354, } \\
\text { Tyr491, Val352, Ala351, } \\
\text { Pro350 }\end{array}$ & Hem & - \\
\hline $6 c$ & -7.66 & Tyr373 & $\begin{array}{l}\text { Ala351, Gln263, Pro350, } \\
\text { Val352, Asp382, Glu377, } \\
\text { Arg381, Trp463 }\end{array}$ & - & - \\
\hline $6 d$ & -8.38 & Tyr373 & $\begin{array}{l}\text { Asn370, Gly371, Pro350, } \\
\text { Ala351, Val352, Glu377, } \\
\text { Asp382, Arg381 }\end{array}$ & - & - \\
\hline $6 e$ & -8.38 & - & $\begin{array}{l}\text { Pro350, Ala351, Asn370, } \\
\text { Gln263, Val352, Gly371, } \\
\text { Tyr347, Tyr373, Glu377, } \\
\text { Asp382, Arg381, Arg388 }\end{array}$ & - & - \\
\hline $6 f$ & -9.25 & Tyr373, Asn354 & $\begin{array}{l}\text { Asn370, Pro350, Gly371, } \\
\text { Phe369, Val352, Glu377, } \\
\text { Asp382, Gln263, Trp346, } \\
\text { Tyr347, Tyr491, Ala262 }\end{array}$ & - & - \\
\hline Dex & -8.01 & $\begin{array}{l}\text { Tyr373, Arg388, } \\
\text { Gln263, Glu377 }\end{array}$ & $\begin{array}{l}\text { Asp382, Val352, Phe369, } \\
\text { Asn370, Pro350, Gly371 }\end{array}$ & - & - \\
\hline
\end{tabular}

Dex $=$ Dexamethasone

Compound $\mathbf{5 c}$ exhibited the best docking score from these computational experiments, and displays the most potent in vitro anti-inflammatory activity after 3o. Molecular docking of $\mathbf{5 c}$ in human inducible nitric oxide synthase revealed an optimal binding mode characterized by the minimum Gibbs binding energy $\left(\Delta \mathrm{G}_{\mathrm{bind}}=-10.74 \mathrm{kcal} / \mathrm{mol}\right)$. As illustrated in the 3D diagram of $\mathbf{5 c}$ 
and in the superimposition of 5c and co-crystallized ligand (Fig. 3), 5c computationally docks almost at the same position as the original co-crystallized ligand. Looking next at the 2D image of the modeled 5c-enzyme modeled (shown on the rightside of Fig. 3), the lactam carbonyl oxygen serves as a hydrogen bond acceptor with the Gln263 (highlighted in the yellow ball) while the other substituents of 5c form hydrophobic interactions with residues Gly371, Asn370, Pro350, Val352, Tyr373, Ala351, Ala262, Arg388, Asn354, Glu377, Arg381 and Asp382 residues.
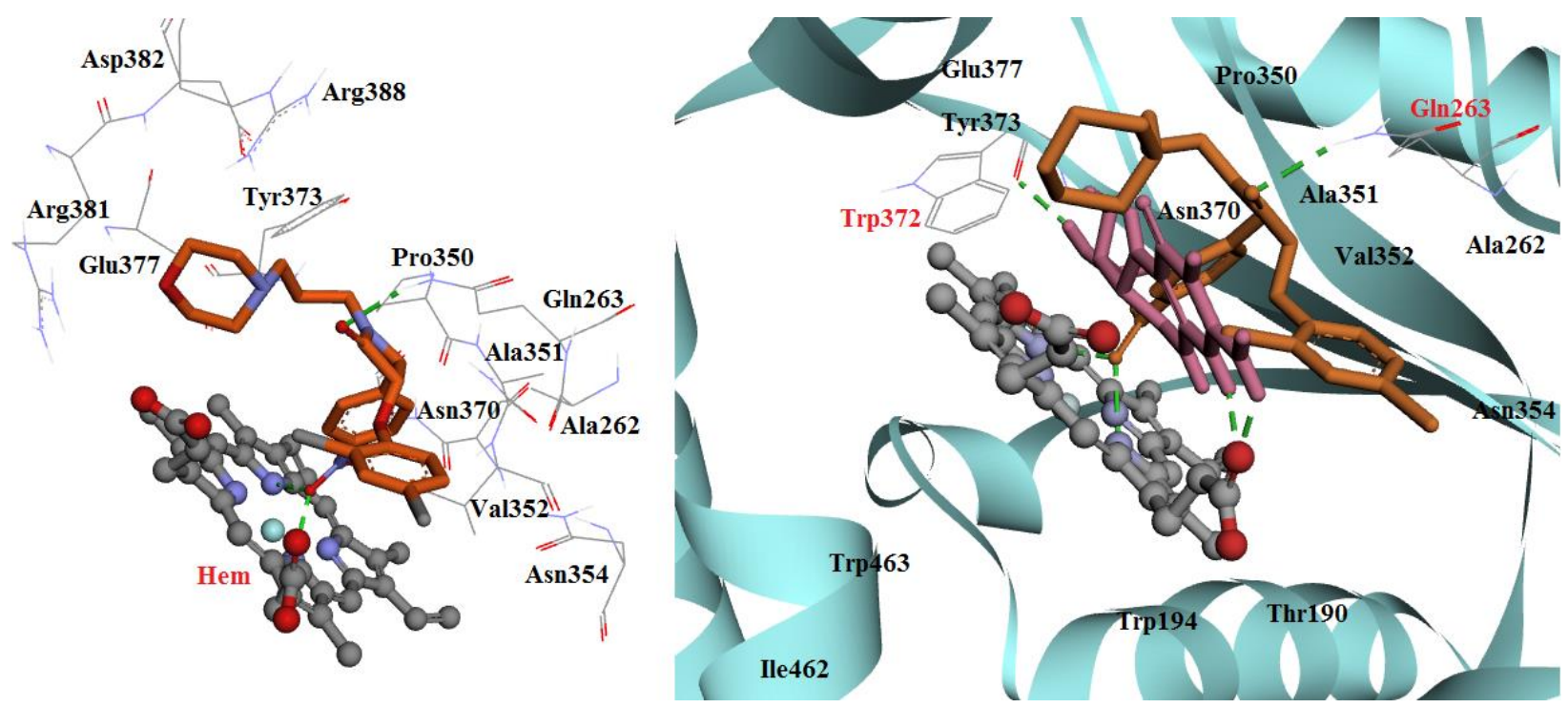

Fig. 3. Compound 5c in the human inducible nitric oxide synthase active site (left) and superimposition of $\mathbf{5 c}$ (brown) and co-crystallized ligand (purple) within binding site.

The presence of an aromatic ring at the $\mathrm{C} 3$ position of the $\beta$-lactam ring showed more potent anti-inflammatory activity than an aliphatic moiety at the same position. For example, compounds 3d, 3f, $\mathbf{3 j}$ and 3n having a methoxy group exhibited poor anti-inflammatory activity compared to $\mathbf{3 a}, \mathbf{3 e}, \mathbf{3 g}$ and $\mathbf{3 k}$ with a phenoxy group. Furthermore, replacing the phenyl ring (3a) with the $p$-chlorophenyl ring (3b) decreased both the anti-inflammatory activity and the nitric oxide synthase docking score. A comparison of the computed binding mode of $\mathbf{3 a}$ and $\mathbf{3 b}$ in the active site of the nitric oxide synthase is shown in Fig. 4. These images indicate that the active site binding modes of $\mathbf{3 a}$ and $\mathbf{3 b}$ are slightly different, such that a non-optimal orientation of $\mathbf{3 b}$ might be the reason for the decrease in both the anti-inflammatory activity and the nitric oxide synthase docking score of $\mathbf{3 b}$ compared to $\mathbf{3 a}$. Specifically, $\mathbf{3} \mathbf{a}$ is computed to form a $\pi-\boldsymbol{\pi}$ stacking interaction with Hem (Figure 4A), while 3b lacks this contact (Figure 4B). 


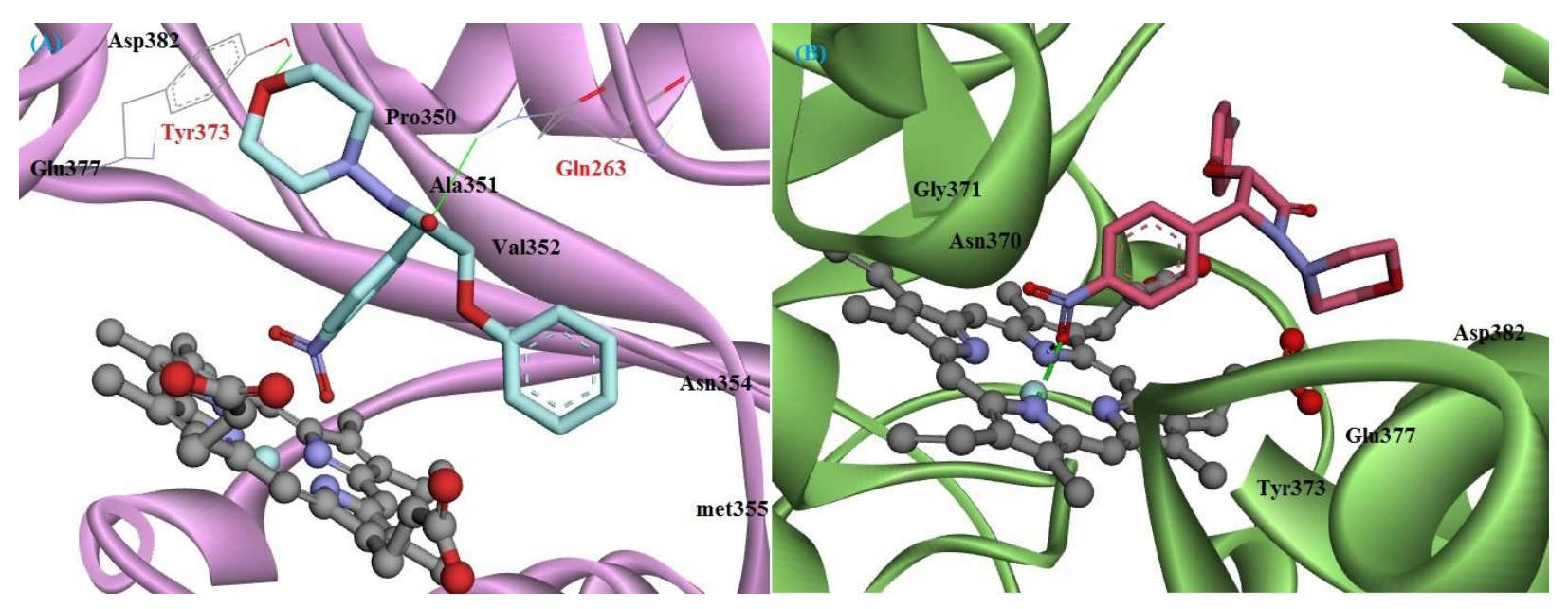

Fig. 4. Computational binding modes of compound $\mathbf{3 a}(\mathbf{A})$ and $\mathbf{3 b}(\mathbf{B})$ in the active site of human inducible nitric oxide synthase.

Similarly, nitrophenyl-substituted $\beta$-lactam analogues $\mathbf{3 d}, \mathbf{3 f}$ and $\mathbf{3 j}$ were computationally docked into the nitric oxide synthase binding site. Fig. 5 shows that the binding modes of $\mathbf{3 d}$ and $\mathbf{3 f}$ are similar but that of $\mathbf{3} \mathbf{j}$ is different. The oxygen atom of the morpholine ring on the lactam nitrogen of $\mathbf{3 d}$ and $\mathbf{3 f}$ forms a tight hydrogen bond with the $\mathrm{NH}$ of Met480, but this stabilizing interaction is not observed for $\mathbf{3 j}$. We attribute this difference to be a plausible explanation for the diminished anti-inflammatory activity of $\mathbf{3 j}$ to $\mathbf{3 d}$ or $\mathbf{3 f}$.

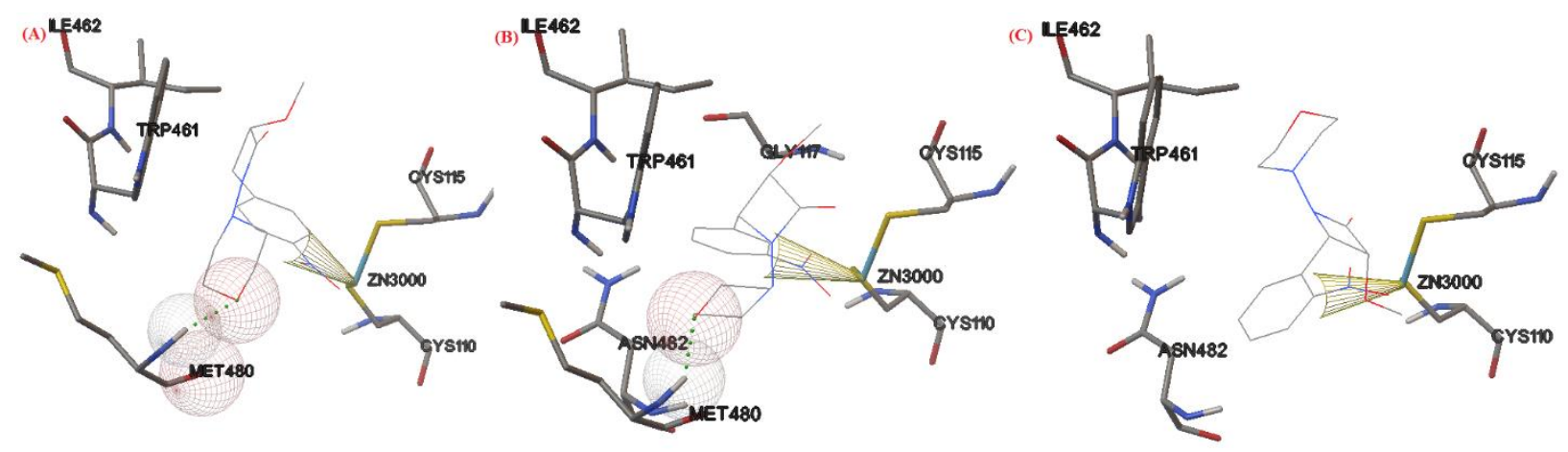

Fig. 5. Superimposition of $\mathbf{3 d}(\mathbf{A}), \mathbf{3 f}(\mathbf{B})$ and $\mathbf{3 j}(\mathbf{C})$ within the nitric oxide synthase binding site.

Furthermore, replacement of the nitrophenyl group of analogue $3 \mathbf{c}$ with a cyanophenyl ring (3m) substantially decreased the in vitro NO inhibition activity, that is borne out in the in silico synthase 
docking studies. The superimposition of compounds $\mathbf{3 c}$ and $\mathbf{3 m}$ are illustrated in Fig. 6, indicating that the nitrophenyl ring of $\mathbf{3} \mathbf{c}$ interacts much more tightly with the porphyrin ring system of the synthase compated to the cyanophenyl ring of $\mathbf{3 m}$.

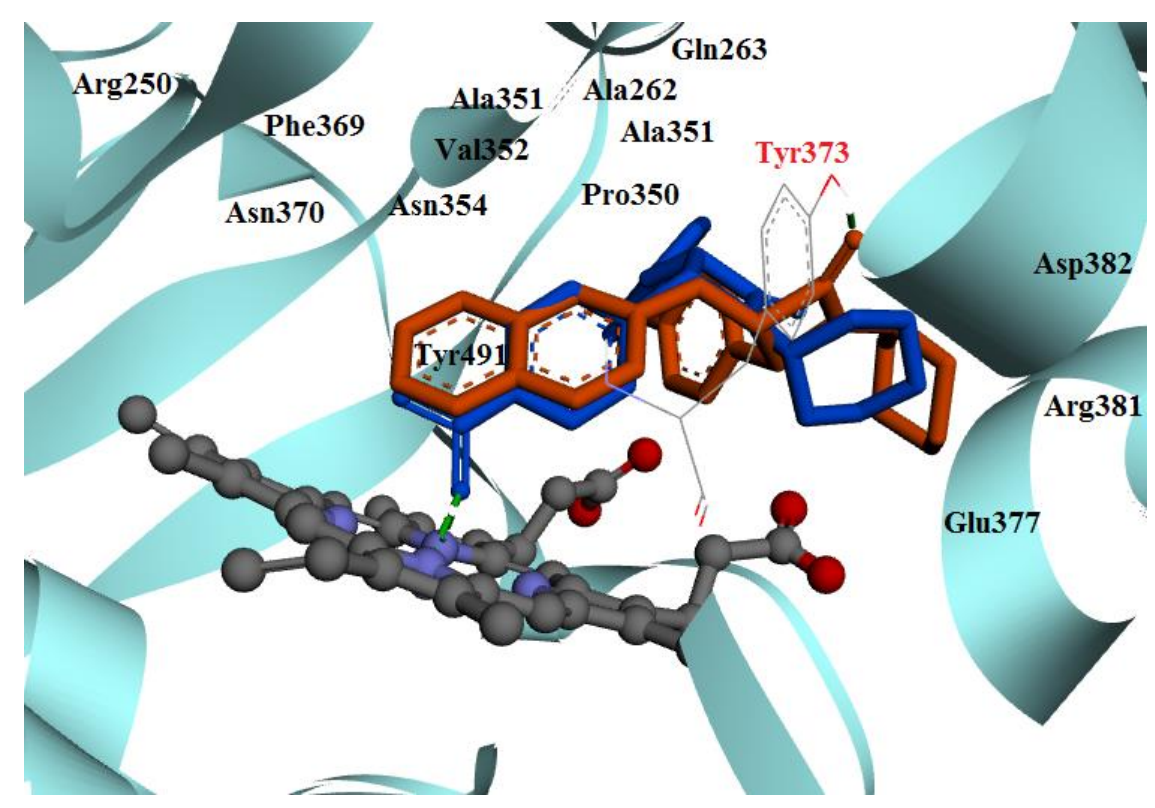

Fig. 6. Superimposition of $\mathbf{3 c}$ (blue) with $\mathbf{3 m}$ (orange) in binding site human inducible nitric oxide synthase enzyme.

We next examined the difference between having the morpholine ring directly attached to the nitrogen of the $\beta$-lactam ring (analogue 3c), versus having it tethered to the nitrogen via a threecarbon alkyl chain (analogue 5d). $N$-Morpholine $\beta$-lactam 3c has weaker in vitro antiinflammatory activity than propylmorpholine $\beta$-lactam 5d (Table 3). Computational modeling suggests that increased alkyl chain length has a negative effect on the active site docking ability (Fig. 7). The greater distance and conformational flexibility of the alkyl tether between the morpholine moiety and the $\beta$-lactam ring is predicted to reduce the effectiveness of reinforcing active site interactions. This should lower the NO inhibitory activity of $\mathbf{5 d}$ versus $\mathbf{3 c}$. However, the opposite is observed. We believe that the sizable difference in lipophilic character of the two compounds may override the potential for stronger active site binding of $3 \mathbf{c}$ over $\mathbf{5 d}$. The calculated $\mathrm{C} \log \mathrm{P}$ of $\mathbf{3 c}(\mathrm{C} \log \mathrm{P}=2.32)$ is considerably lower than that of $\mathbf{5 d}(\mathrm{C} \log \mathrm{P}=4.67)$, which predicts 
a much reduced capability of $\mathbf{3 c}$ to penetrate the cell membrane, and this could be a reason for $\mathbf{3 c}$ having lower anti-inflammatory potency than $\mathbf{5 d}$.

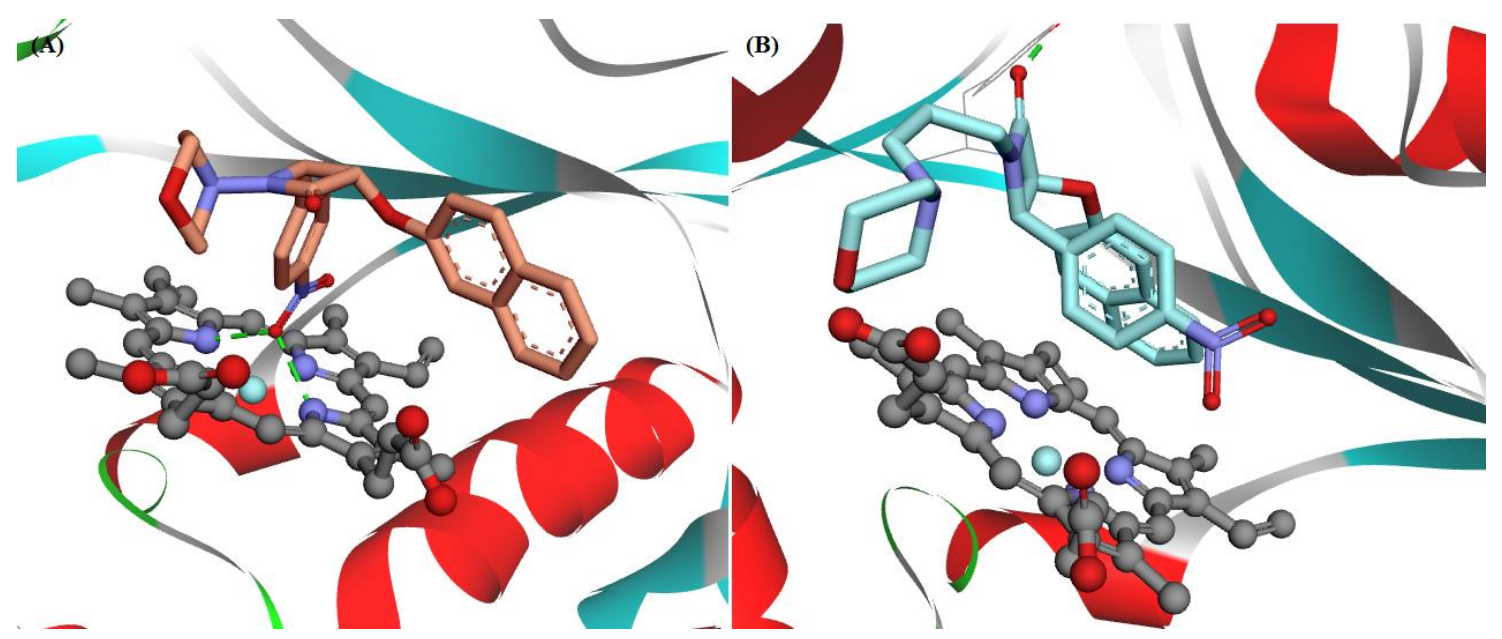

Fig. 7. Computational docking of $\mathbf{3 c}(\mathbf{A})$ and $\mathbf{5 d}(\mathbf{B})$ into the active site of human inducible nitric oxide synthase

Replacing the $\mathrm{C} 4$ nitrophenyl ring substituent (5c) with the corresponding $\mathrm{C} 4$ aminophenyl moiety (6c) simultaneously diminished the in vitro anti-inflammatory activity and the computational docking score (Table 3 and 4). This suggests that the $\mathrm{NO}_{2}$ substituent may exert more favorable active site binding, as illustrated in the more fitted, flattened orientation of 5c versus $\mathbf{6 c}$ in the human nitric acid synthase active site (Fig. 8).
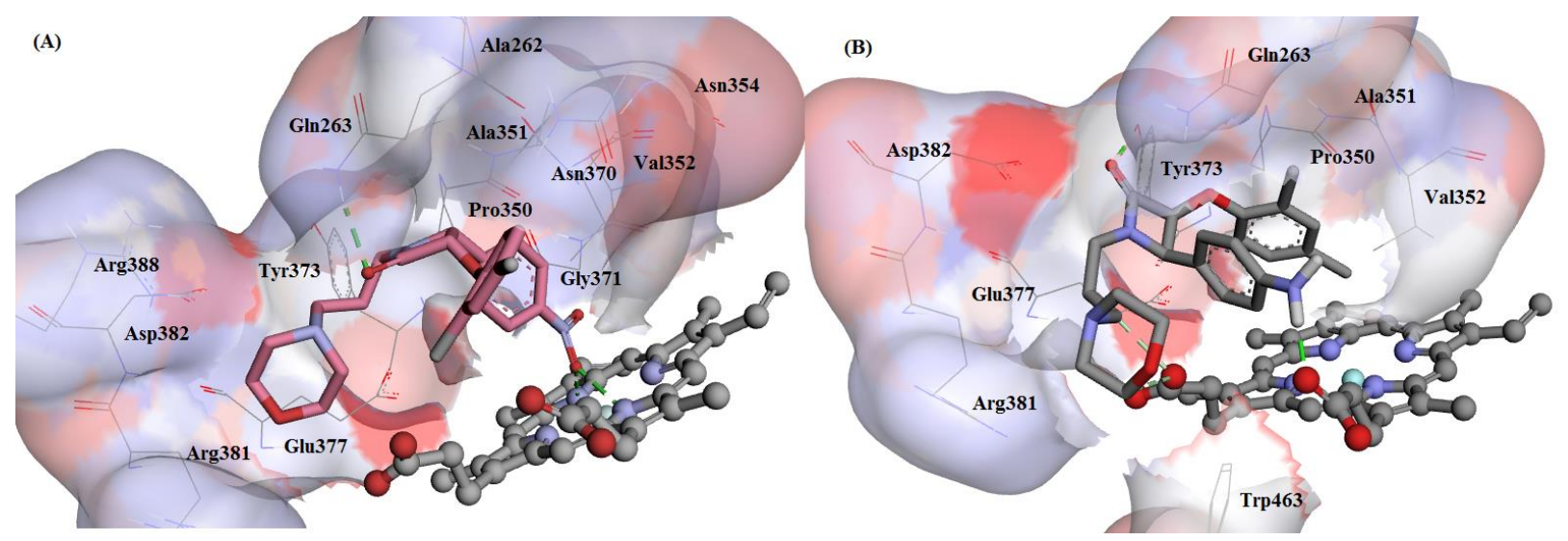

Fig. 8. Interactions of $\mathbf{5 c}(\mathbf{A})$ and $\mathbf{6 c}(\mathbf{B})$ in the active site of human inducible nitric oxide synthase 
Additionally, placement of an additional chlorine substituent on the C3 phenyl ring of para-chlorophenyl derivatives $\mathbf{5 b}$ and $\mathbf{6 b}$ with a second chlorine at the meta position (5c and $\mathbf{6 c}$ ) further enhanced the in vitro anti-inflammatory activity and in silico enzyme binding affinity (Tables 3 and 4). This suggests that the presence of two chlorine atoms enhances opportunities for favorable hydrophobic interactions with active site residues, versus the mono-chlorophenyl substituent $(\mathrm{C} \log \mathrm{P}=3.91$ for $\mathbf{6 c}$ vs. $\mathrm{C} \log \mathrm{P}=3.38$ for $\mathbf{6 b})$. In summary, $\beta$-lactams 6a-e exhibited the weakest affinity to the substrate binding region of the NO synthase enzyme, compared to analogues 3a-o and 5a-h. Our molecular docking results suggest that compounds 3a, 3i, 3k, 3o, $\mathbf{5 b}, \mathbf{5 d}, \mathbf{6 a}$, and $\mathbf{6 b}$ all form a favorable $\pi-\pi$ stacking interaction with Hem or Trp461 in the binding pocket (Fig. 9).

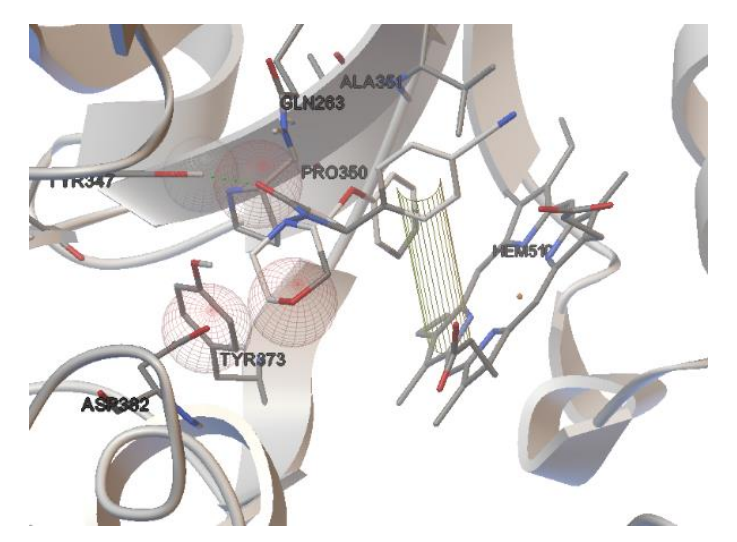

Fig. 9. Close-up view of the computational docking of $\mathbf{3 k}$ within the active site of human inducible nitric oxide synthase.

\section{Materials}

Chemicals were obtained from the Fluka, Merck, and Acros chemical companies. $\mathrm{CH}_{2} \mathrm{Cl}_{2}$ and $\mathrm{Et}_{3} \mathrm{~N}$ were dried by distillation over $\mathrm{CaH}_{2}$ and then stored over $4 \mathrm{~A}^{\circ}$ molecular sieves. ${ }^{1} \mathrm{H}$ $\mathrm{NMR}$ and ${ }^{13} \mathrm{C}-\mathrm{NMR}$ spectra were recorded in $\mathrm{CDCl}_{3}$ or DMSO- $\mathrm{d}_{6}$ using a Bruker Avance DPX instrument (operating at $250 \mathrm{MHz}$ for ${ }^{1} \mathrm{H}-\mathrm{NMR}$ and $62.9 \mathrm{MHz}$ for ${ }^{13} \mathrm{C}-\mathrm{NMR}$ ). Chemical shifts were reported in ppm $(\delta)$ downfield from TMS. All the coupling constants $(J)$ are in Hertz. FTIR spectra were run on a Shimadzu FT-IR 8300 spectrophotometer. The mass spectra were recorded on a Shimadzu Mass spectra were obtained on a Shimadzu GCMS-QP 1000 EX instrument at 70 eV. Elemental analyses were run on a Thermo Finnigan Flash EA-1112 series. Melting points were 
determined in open capillary tubes in Thermo Fisher scientific IA9200 apparatus and are uncorrected. The progress of the reactions was monitored by TLC on silica gel 254 analytical sheets obtained from Fluka and purification was achieved by silica gel column chromatography on Merck Kieselgel (230-270 mesh).

\section{General Procedure for the Synthesis of Monocyclic $\beta$-Lactams (3a-o):}

A solution of the corresponding Schiff base (1) $(1.00 \mathrm{mmol})$ was stirred with the corresponding substituted acetic acid (2) (1.50 mmol), $p$-toluenesulfonyl chloride $(1.50 \mathrm{mmol})$ and triethylamine $(2.50 \mathrm{mmol})$ in dry $\mathrm{CH}_{2} \mathrm{Cl}_{2}$ at room temperature. After $24 \mathrm{~h}$, the mixture was washed with $1 \mathrm{~N}$ aqueous $\mathrm{HCl}$ solution $(20 \mathrm{~mL})$, saturated aqueous $\mathrm{NaHCO}_{3}$ solution $(20 \mathrm{~mL})$, brine $(20$ $\mathrm{mL}$ ), dried over anhydrous $\mathrm{Na}_{2} \mathrm{SO}_{4}$ and then filtered. After evaporation of solvent, the crude $\beta$ lactam products (3a-o) were purified by silica gel column chromatography (eluent 2:1 nhexane/EtOAc).

\section{1-Morpholino-4-(4-nitrophenyl)-3-phenoxyazetidin-2-one (3a)}

Cream-colored solid (yield $32 \%$ ). mp 164-166 ${ }^{\circ} \mathrm{C}$. IR (KBr, cm $\left.{ }^{-1}\right) 1774$ (CO, $\beta$-lactam), 1342, $1520\left(\mathrm{NO}_{2}\right) .{ }^{1} \mathrm{H}-\mathrm{NMR}\left(\mathrm{CDCl}_{3}\right) \delta 2.93\left(\mathrm{CH}_{2}-\mathrm{N}, 2 \mathrm{H}, \mathrm{m}\right), 3.09\left(\mathrm{CH}_{2}-\mathrm{N}, 2 \mathrm{H}, \mathrm{m}\right) 3.68\left(\mathrm{CH}_{2}-\mathrm{O}\right.$, 4H, m), $4.41(\mathrm{H}-4, \mathrm{~d}, J=4.6 \mathrm{~Hz}, 1 \mathrm{H}), 5.35(\mathrm{H}-3, \mathrm{~d}, J=4.6 \mathrm{~Hz}, 1 \mathrm{H}), 6.68$ (ArH, d, J = 7.8 Hz, 2H), $6.86(\mathrm{ArH}, \mathrm{t}, J=7.3 \mathrm{~Hz}, 1 \mathrm{H}), 7.09$ (ArH, t, $J=7.3 \mathrm{~Hz}, 2 \mathrm{H}), 7.63(\mathrm{ArH}, \mathrm{d}, J=8.6 \mathrm{~Hz}, 2 \mathrm{H}), 8.14$ $(\mathrm{ArH}, \mathrm{d}, J=8.6 \mathrm{~Hz}, 2 \mathrm{H}) .{ }^{13} \mathrm{C}-\mathrm{NMR}\left(\mathrm{CDCl}_{3}\right) \delta 53.5\left(\mathrm{CH}_{2}-\mathrm{N}\right), 66.2\left(\mathrm{CH}_{2}-\mathrm{O}\right), 62.3(\mathrm{C}-4), 79.3(\mathrm{C}-$ 3), 115.2, 122.5, 123.4, 129.4, 129.8, 141.3, 148.2, 156.3 (aromatic carbons), 164.1 (CO, $\beta$ lactam). $\mathrm{MS} \mathrm{m} / \mathrm{z}=369\left[\mathrm{M}^{+}\right]$. Anal. Calcd. for $\mathrm{C}_{19} \mathrm{H}_{19} \mathrm{~N}_{3} \mathrm{O}_{5}: \mathrm{C}, 61.78 ; \mathrm{H}, 5.18 ; \mathrm{N}, 11.38 \%$. Found: C, $61.65 ; \mathrm{H}, 5.29 ; \mathrm{N}, 11.25 \%$.

\section{3-(4-Chlorophenoxy)-1-morpholino-4-(4-nitrophenyl) azetidin-2-one (3b)}

White crystals (yield $35 \%$ ). mp 216-218 ${ }^{\circ} \mathrm{C}$. IR (KBr, cm $\left.{ }^{-1}\right) 1786$ (CO, $\beta$-lactam), 1346, $1520\left(\mathrm{NO}_{2}\right) .{ }^{1} \mathrm{H}-\mathrm{NMR}\left(\mathrm{CDCl}_{3}\right) \delta 2.91\left(\mathrm{CH}_{2}-\mathrm{N}, \mathrm{m}, 2 \mathrm{H}\right), 3.07\left(\mathrm{CH}_{2}-\mathrm{N}, \mathrm{m}, 2 \mathrm{H}\right), 3.65\left(\mathrm{CH}_{2}-\mathrm{O}, \mathrm{m}\right.$, 4H), $5.24(\mathrm{H}-4, \mathrm{~d}, J=4.9 \mathrm{~Hz}, 1 \mathrm{H}), 5.28(\mathrm{H}-3, \mathrm{~d}, J=4.9 \mathrm{~Hz}, 1 \mathrm{H}), 6.65(\mathrm{ArH}, \mathrm{d}, J=9.0 \mathrm{~Hz}, 2 \mathrm{H})$, $7.07(\mathrm{ArH}, \mathrm{d}, J=9.0 \mathrm{~Hz}, 2 \mathrm{H}), 7.62(\mathrm{ArH}, \mathrm{d}, J=8.8 \mathrm{~Hz}, 2 \mathrm{H}), 8.18(\mathrm{ArH}, \mathrm{d}, J=8.8 \mathrm{~Hz}, 2 \mathrm{H}) .{ }^{13} \mathrm{C}-$ NMR $\left(\mathrm{CDCl}_{3}\right) \delta 53.5\left(\mathrm{CH}_{2}-\mathrm{N}\right), 62.2(\mathrm{C}-4), 66.2\left(\mathrm{CH}_{2}-\mathrm{O}\right), 79.4(\mathrm{C}-3), 116.6,123.5,127.6,129.4$, 
129.8, 141.0, 148.3, 154.9 (aromatic carbons), 163.8 (CO, $\beta$-lactam). MS m/z = 403 [M+ ${ }^{+}$. Anal. Calcd. for $\mathrm{C}_{19} \mathrm{H}_{18} \mathrm{ClN}_{3} \mathrm{O}_{5}: \mathrm{C}, 56.51 ; \mathrm{H}, 4.49 ; \mathrm{N}, 10.41 \%$. Found: C, 56.58; H, 4.61; N, $10.40 \%$.

\section{1-Morpholino-3-(naphthalen-2-yloxy)-4-(4-nitrophenyl) azetidin-2-one (3c)}

Cream-colored solid (yield $38 \%$ ). mp 236-238 ${ }^{\circ} \mathrm{C}$. IR (KBr, $\left.\mathrm{cm}^{-1}\right) 1767$ (CO, $\beta$-lactam), 1350, $1520\left(\mathrm{NO}_{2}\right) .{ }^{1} \mathrm{H}-\mathrm{NMR}\left(\mathrm{CDCl}_{3}\right) \delta 2.86\left(\mathrm{CH}_{2}-\mathrm{N}, \mathrm{m}, 4 \mathrm{H}\right), 3.57\left(\mathrm{CH}_{2}-\mathrm{O}, \mathrm{m}, 4 \mathrm{H}\right), 5.26(\mathrm{H}-4, \mathrm{~d}$, $J=4.6 \mathrm{~Hz}, 1 \mathrm{H}), 5.41(\mathrm{H}-3, \mathrm{~d}, J=4.6 \mathrm{~Hz}, 1 \mathrm{H}), 6.79$ (ArH, d, $J=8.9 \mathrm{~Hz}, 1 \mathrm{H}), 6.94$ (ArH, s, 1H), 7.18-7.34 (ArH, m, 2H), $7.50(\mathrm{ArH}, \mathrm{d}, J=9.2 \mathrm{~Hz}, 2 \mathrm{H}), 7.58$ (ArH, d, $J=8.8 \mathrm{~Hz}, 2 \mathrm{H}), 7.59$ (ArH, $\mathrm{d}, J=8.9 \mathrm{~Hz}, 1 \mathrm{H}), 8.04(\mathrm{ArH}, \mathrm{d}, J=8.8 \mathrm{~Hz}, 2 \mathrm{H}) .{ }^{13} \mathrm{C}-\mathrm{NMR}\left(\mathrm{CDCl}_{3}\right) \delta 53.5\left(\mathrm{CH}_{2}-\mathrm{N}\right), 62.4(\mathrm{C}-4)$, $66.2\left(\mathrm{CH}_{2}-\mathrm{O}\right), 79.2$ (C-3), 108.7, 117.9, 123.4, 124.5, 126.7, 126.8, 127.7, 129.6, 129.8, 133.7, 141.2, 148.9, 157.3 (aromatic carbons), 163.9 (CO, $\beta$-lactam). MS m/z = 419 [M+ $\mathrm{M}^{+}$. Anal. Calcd. for $\mathrm{C}_{23} \mathrm{H}_{21} \mathrm{~N}_{3} \mathrm{O}_{5}$ : C, 65.86; H, 5.05; N, $10.02 \%$. Found: C, 66.01; H, 5.12; N, $9.89 \%$.

\section{3-Methoxy-1-morpholino-4-(4-nitrophenyl) azetidin-2-one (3d)}

White crystals (yield $45 \%$ ). mp 172-174 ${ }^{\circ} \mathrm{C}$. IR (KBr, $\left.\mathrm{cm}^{-1}\right) 1782$ (CO, $\beta$-lactam), 1350, $1520\left(\mathrm{NO}_{2}\right) .{ }^{1} \mathrm{H}-\mathrm{NMR}\left(\mathrm{CDCl}_{3}\right) \delta 2.80\left(\mathrm{CH}_{2}-\mathrm{N}, \mathrm{m}, 4 \mathrm{H}\right), 3.08(\mathrm{OMe}, \mathrm{s}, 3 \mathrm{H}), 3.60\left(\mathrm{CH}_{2}-\mathrm{O}, \mathrm{m}, 4 \mathrm{H}\right)$, $4.57(\mathrm{H}-4, \mathrm{~d}, J=4.8 \mathrm{~Hz}, 1 \mathrm{H}), 5.06(\mathrm{H}-3, \mathrm{~d}, J=4.8 \mathrm{~Hz}, 1 \mathrm{H}), 7.61$ (ArH, d, $J=8.7 \mathrm{~Hz}, 2 \mathrm{H}), 8.19$ $(\mathrm{ArH}, \mathrm{d}, J=8.7 \mathrm{~Hz}, 2 \mathrm{H}) .{ }^{13} \mathrm{C}-\mathrm{NMR}\left(\mathrm{CDCl}_{3}\right) \delta 53.4\left(\mathrm{CH}_{2}-\mathrm{N}\right), 58.6(\mathrm{OMe}), 61.8(\mathrm{C}-4), 66.2\left(\mathrm{CH}_{2}-\right.$ O), 83.1 (C-3), 123.4, 129.7, 142.0, 148.1 (aromatic carbons), 165.2 (CO, $\beta$-lactam). MS m/z = 307[ $\left.\mathrm{M}^{+}\right]$. Anal. Calcd. for $\mathrm{C}_{14} \mathrm{H}_{17} \mathrm{~N}_{3} \mathrm{O}_{5}$ : C, 54.72; H, 5.58; N, $13.67 \%$. Found: C, 54.80; H, 5.67; $\mathrm{N}, 13.59 \%$.

\section{1-Morpholino-4-(3-nitrophenyl)-3-phenoxyazetidin-2-one (3e)}

Light brown solid (yield $25 \%$ ). mp 134-136 ${ }^{\circ} \mathrm{C}$. IR (KBr, $\left.\mathrm{cm}^{-1}\right) 1770$ (CO, $\beta$-lactam), 1350, $1527\left(\mathrm{NO}_{2}\right) .{ }^{1} \mathrm{H}-\mathrm{NMR}\left(\mathrm{CDCl}_{3}\right) \delta 2.96\left(\mathrm{CH}_{2}-\mathrm{N}, \mathrm{m}, 2 \mathrm{H}\right) .3 .10\left(\mathrm{CH}_{2}-\mathrm{N}, \mathrm{m}, 2 \mathrm{H}\right), 3.66\left(\mathrm{CH}_{2}-\mathrm{O}, \mathrm{m}\right.$, 4H), $5.27(\mathrm{H}-4, \mathrm{~d}, J=4.7 \mathrm{~Hz}, 1 \mathrm{H}), 5.35(\mathrm{H}-3, \mathrm{~d}, J=4.7 \mathrm{~Hz}, 1 \mathrm{H}), 6.67$ (ArH, d, $J=8.5 \mathrm{~Hz}, 2 \mathrm{H})$, $6.87(\mathrm{ArH}, \mathrm{t}, J=7.4 \mathrm{~Hz}, 1 \mathrm{H}), 7.08(\mathrm{ArH}, \mathrm{t}, J=8.5 \mathrm{~Hz}, 2 \mathrm{H}), 7.49(\mathrm{ArH}, \mathrm{t}, J=8.0 \mathrm{~Hz}, 1 \mathrm{H}), 7.80$

$(\mathrm{ArH}, \mathrm{d}, J=8.0 \mathrm{~Hz}, 1 \mathrm{H}), 8.11(\mathrm{ArH}, \mathrm{d}, J=8.5 \mathrm{~Hz}, 1 \mathrm{H}), 8.31(\mathrm{ArH}, \mathrm{s}, 1 \mathrm{H}) .{ }^{13} \mathrm{C}-\mathrm{NMR}\left(\mathrm{CDCl}_{3}\right) \delta$ $53.5\left(\mathrm{CH}_{2}-\mathrm{N}\right), 62.3(\mathrm{C}-4), 66.2\left(\mathrm{CH}_{2}-\mathrm{O}\right), 79.1$ (C-3), 115.2, 122.4, 123.9, 123.9, 129.2, 129.4, 134.8, 136.2, 148.0, 156.2 (aromatic carbons), 164.1 (CO, $\beta$-lactam). MS m/z = 369 [M+ ${ }^{+}$. Anal. Calcd. for $\mathrm{C}_{19} \mathrm{H}_{19} \mathrm{~N}_{3} \mathrm{O}_{5}$ : C, 61.78; H, 5.18; N, $11.38 \%$. Found: C, 61.69; H, 5.29; N, $11.35 \%$. 
3-Methoxy-1-morpholino-4-(3-nitrophenyl) azetidin-2-one (3f)

White crystals (yield 43\%). mp 156-158 ${ }^{\circ} \mathrm{C}$. IR (KBr, $\left.\mathrm{cm}^{-1}\right) 1782$ (CO, $\beta$-lactam), 1342, 1535 $\left(\mathrm{NO}_{2}\right) .{ }^{1} \mathrm{H}-\mathrm{NMR}\left(\mathrm{CDCl}_{3}\right) \delta 2.86\left(\mathrm{CH}_{2}-\mathrm{N}, \mathrm{m}, 4 \mathrm{H}\right), 3.14(\mathrm{OMe}, \mathrm{s}, 3 \mathrm{H}), 3.63\left(\mathrm{CH}_{2}-\mathrm{O}, \mathrm{m}, 4 \mathrm{H}\right), 4.57$ $(\mathrm{H}-4, \mathrm{~d}, J=4.8 \mathrm{~Hz}, 1 \mathrm{H}), 5.06(\mathrm{H}-3, \mathrm{~d}, J=4.8 \mathrm{~Hz}, 1 \mathrm{H}), 7.55(\mathrm{ArH}, \mathrm{t}, J=7.9 \mathrm{~Hz}, 1 \mathrm{H}), 7.80(\mathrm{ArH}$, $\mathrm{d}, J=7.9 \mathrm{~Hz}, 1 \mathrm{H}), 8.22(\mathrm{ArH}, \mathrm{d}, J=8.1 \mathrm{~Hz}, 1 \mathrm{H}), 8.30(\mathrm{ArH}, \mathrm{s}, 1 \mathrm{H}) .{ }^{13} \mathrm{C}-\mathrm{NMR}\left(\mathrm{CDCl}_{3}\right) \delta 53.5$ $\left(\mathrm{CH}_{2}-\mathrm{N}\right), 58.6(\mathrm{OMe}), 61.9(\mathrm{C}-4), 66.2\left(\mathrm{CH}_{2}-\mathrm{O}\right), 82.8(\mathrm{C}-3), 123.8,129.3,134.7,136.8,148.2$ (aromatic carbons), $165.3\left(\mathrm{CO}, \beta\right.$-lactam). $\mathrm{MS} \mathrm{m} / \mathrm{z}=307\left[\mathrm{M}^{+}\right]$. Anal. Calcd. for $\mathrm{C}_{14} \mathrm{H}_{17} \mathrm{~N}_{3} \mathrm{O}_{5}: \mathrm{C}$, 54.72; H, 5.58; N, $13.67 \%$. Found: C, 54.67; H, 5.65; N, $13.71 \%$.

\section{1-Morpholino-4-(2-nitrophenyl)-3-phenoxyazetidin-2-one (3g)}

Cream-colored crystals (yield $36 \%$ ). mp 184-186 ${ }^{\circ} \mathrm{C}$. IR (KBr, cm $\left.{ }^{-1}\right) 1767$ (CO, $\beta$-lactam), 1354, $1527\left(\mathrm{NO}_{2}\right) .{ }^{1} \mathrm{H}-\mathrm{NMR}\left(\mathrm{CDCl}_{3}\right) \delta 3.16\left(\mathrm{CH}_{2}-\mathrm{N}, \mathrm{m}, 4 \mathrm{H}\right), 3.66\left(\mathrm{CH}_{2}-\mathrm{O}, \mathrm{m}, 4 \mathrm{H}\right), 5.42(\mathrm{H}-4, \mathrm{~d}$, $J=5.1 \mathrm{~Hz}, 1 \mathrm{H}), 5.84(\mathrm{H}-3, \mathrm{~d}, J=5.1 \mathrm{~Hz}, 1 \mathrm{H}), 6.78(\mathrm{ArH}, \mathrm{d}, J=8.5 \mathrm{~Hz}, 2 \mathrm{H}), 6.89$ (ArH, t, $J=7.5$ $\mathrm{Hz}, 1 \mathrm{H}), 7.10$ (ArH, t, $J=8.5 \mathrm{~Hz}, 2 \mathrm{H}), 7.47$ (ArH, t, $J=8.6 \mathrm{~Hz}, 1 \mathrm{H}), 7.68$ (ArH, t, $J=8.2 \mathrm{~Hz}$, 1H), $7.81(\mathrm{ArH}, \mathrm{d}, J=8.6 \mathrm{~Hz}, 1 \mathrm{H}), 8.01(\mathrm{ArH}, \mathrm{d}, J=8.2 \mathrm{~Hz}, 1 \mathrm{H}) .{ }^{13} \mathrm{C}-\mathrm{NMR}\left(\mathrm{CDCl}_{3}\right) \delta 53.2\left(\mathrm{CH}_{2^{-}}\right.$ N), 59.5 (C-4), $66.5\left(\mathrm{CH}_{2}-\mathrm{O}\right), 80.2$ (C-3), 115.8, 122.5, 124.9, 129.2, 129.4, 129.9, 130.5, 133.2, 148.8, 156.8 (aromatic carbons), 165.8 (CO, $\beta$-lactam). MS m/z = $369\left[\mathrm{M}^{+}\right]$. Anal. Calcd. for $\mathrm{C}_{19} \mathrm{H}_{19} \mathrm{~N}_{3} \mathrm{O}_{5}$ : C, 61.78; H, 5.18; N, $11.38 \%$. Found: C, 61.85; H, 5.37; N, $11.42 \%$.

\section{3-(4-Chlorophenoxy)-1-morpholino-4-(2-nitrophenyl) azetidin-2-one (3h)}

Cream-colored crystals (yield $23 \%)$ mp 152-154 ${ }^{\circ} \mathrm{C}$. IR $\left(\mathrm{KBr}, \mathrm{cm}^{-1}\right) 1782$ (CO, $\beta$-lactam), 1342, $1527\left(\mathrm{NO}_{2}\right) .{ }^{1} \mathrm{H}-\mathrm{NMR}\left(\mathrm{CDCl}_{3}\right) \delta 3.21\left(\mathrm{CH}_{2}-\mathrm{N}, \mathrm{m}, 4 \mathrm{H}\right), 3.72\left(\mathrm{CH}_{2}-\mathrm{O}, \mathrm{m}, 4 \mathrm{H}\right), 5.36(\mathrm{H}-4, \mathrm{~d}$, $J=5.0 \mathrm{~Hz}, 1 \mathrm{H}), 5.81(\mathrm{H}-3, \mathrm{~d}, J=5.0 \mathrm{~Hz}, 1 \mathrm{H}), 6.75(\mathrm{ArH}, \mathrm{d}, J=8.6 \mathrm{~Hz}, 2 \mathrm{H}), 7.09(\mathrm{ArH}, \mathrm{d}, J=$ $8.6 \mathrm{~Hz}, 2 \mathrm{H}), 7.49$ (ArH, t, $J=7.5 \mathrm{~Hz}, 1 \mathrm{H}), 7.68(\mathrm{ArH}, \mathrm{t}, J=7.5 \mathrm{~Hz}, 1 \mathrm{H}), 7.80(\mathrm{ArH}, \mathrm{d}, J=7.6 \mathrm{~Hz}$, $1 \mathrm{H}), 8.00(\mathrm{ArH}, \mathrm{d}, J=8.1 \mathrm{~Hz}, 1 \mathrm{H}) .{ }^{13} \mathrm{C}-\mathrm{NMR}\left(\mathrm{CDCl}_{3}\right) \delta 53.2\left(\mathrm{CH}_{2}-\mathrm{N}\right), 59.6(\mathrm{C}-4), 66.5\left(\mathrm{CH}_{2}-\mathrm{O}\right)$, 80.4 (C-3), 117.3, 125.1, 128.8, 129.3, 129.7, 130.3, 130.9, 133.3, 148.7, 155.4 (aromatic carbons), 165.5 (CO, $\beta$-lactam). $\mathrm{MS} \mathrm{m} / \mathrm{z}=403\left[\mathrm{M}^{+}\right]$. Anal. Calcd. for $\mathrm{C}_{19} \mathrm{H}_{18} \mathrm{ClN}_{3} \mathrm{O}_{5}: \mathrm{C}, 56.51 ; \mathrm{H}, 4.49 ; \mathrm{N}$, $10.41 \%$. Found: C, 56.60; H, 4.62; N, $10.36 \%$. 
1-Morpholino-3-(naphthalen-2-yloxy)-4-(2-nitrophenyl) azetidin-2-one (3i)

Cream-colored solid (yield $38 \%$ ); mp 202-204 ${ }^{\circ} \mathrm{C}$; IR $\left(\mathrm{KBr}, \mathrm{cm}^{-1}\right) 1767$ (CO, $\beta$-lactam), 1342, $1527\left(\mathrm{NO}_{2}\right) .{ }^{1} \mathrm{H}-\mathrm{NMR}\left(\mathrm{CDCl}_{3}\right) \delta 3.16\left(\mathrm{CH}_{2}-\mathrm{N}, \mathrm{m}, 4 \mathrm{H}\right), 3.72\left(\mathrm{CH}_{2}-\mathrm{O}, \mathrm{m}, 4 \mathrm{H},\right), 5.57(\mathrm{H}-4, \mathrm{~d}$, $J=5.1 \mathrm{~Hz}, 1 \mathrm{H}), 5.92(\mathrm{H}-3, \mathrm{~d}, J=5.1 \mathrm{~Hz}, 1 \mathrm{H}), 6.87(\mathrm{ArH}, \mathrm{d}, J=8.9 \mathrm{~Hz}, 1 \mathrm{H}), 7.26(\mathrm{ArH}, \mathrm{s}, 1 \mathrm{H})$, 7.31-7.45 (ArH, m, 3H), 7.57 (ArH, d, $J=8.9 \mathrm{~Hz}, 2 \mathrm{H}), 7.66(\mathrm{ArH}, \mathrm{d}, J=9.1 \mathrm{~Hz}, 2 \mathrm{H}), 7.85(\mathrm{ArH}$, d, $J=7.9 \mathrm{~Hz}, 1 \mathrm{H}), 7.96(\mathrm{ArH}, \mathrm{d}, J=8.2 \mathrm{~Hz}, 1 \mathrm{H}) .{ }^{13} \mathrm{C}-\mathrm{NMR}\left(\mathrm{CDCl}_{3}\right) \delta 53.3\left(\mathrm{CH}_{2}-\mathrm{N}\right), 59.3(\mathrm{C}-4)$, $66.5\left(\mathrm{CH}_{2}-\mathrm{O}\right), 80.2$ (C-3), 109.6, 118.1, 124.4, 124.9, 126.5, 127.1, 127.5, 129.3, 129.5, 129.6, 129.9, 130.1, 133.1, 133.9, 148.9, 154.5 (aromatic carbons), 165.5 (CO, $\beta$-lactam). MS m/z = 419 $\left[\mathrm{M}^{+}\right]$. Anal. Calcd. for $\mathrm{C}_{23} \mathrm{H}_{21} \mathrm{~N}_{3} \mathrm{O}_{5}: \mathrm{C}, 65.86 ; \mathrm{H}, 5.05 ; \mathrm{N}, 10.02 \%$. Found: $\mathrm{C}, 65.90 ; \mathrm{H}, 5.17 ; \mathrm{N}$, $10.00 \%$.

\section{3-Methoxy-1-morpholino-4-(2-nitrophenyl) azetidin-2-one (3j)}

White solid (yield $64 \%$ ). mp 180-182 ${ }^{\circ} \mathrm{C}$; IR ( $\left.\mathrm{KBr}, \mathrm{cm}^{-1}\right) 1767$ (CO, $\beta$-lactam), 1342, 1520 $\left(\mathrm{NO}_{2}\right) .{ }^{1} \mathrm{H}-\mathrm{NMR}\left(\mathrm{CDCl}_{3}\right) \delta 3.08\left(\mathrm{CH}_{2}-\mathrm{N}, \mathrm{m}, 4 \mathrm{H}\right), 3.21(\mathrm{OMe}, \mathrm{s}, 3 \mathrm{H}), 3.61\left(\mathrm{CH}_{2}-\mathrm{O}, \mathrm{m}, 4 \mathrm{H}\right), 4.68$ $(\mathrm{H}-4, \mathrm{~d}, J=5.0 \mathrm{~Hz}, 1 \mathrm{H}), 5.51(\mathrm{H}-3, \mathrm{~d}, J=5.0 \mathrm{~Hz}, 1 \mathrm{H}), 7.47(\mathrm{ArH}, \mathrm{t}, J=8.7 \mathrm{~Hz}, 1 \mathrm{H}), 7.65(\mathrm{ArH}$, t, $J=7.9 \mathrm{~Hz}, 1 \mathrm{H}), 7.72(\mathrm{ArH}, \mathrm{d}, J=7.9 \mathrm{~Hz}, 1 \mathrm{H}), 8.03(\mathrm{ArH}, \mathrm{d}, J=8.1 \mathrm{~Hz}, 1 \mathrm{H}) .{ }^{13} \mathrm{C}-\mathrm{NMR}\left(\mathrm{CDCl}_{3}\right)$

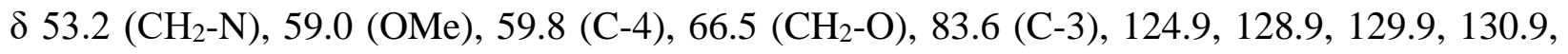
133.2, 148.8 (aromatic carbons), 166.9 (CO, $\beta$-lactam). MS m/z = 307 [M+]; Anal. Calcd. for $\mathrm{C}_{14} \mathrm{H}_{17} \mathrm{~N}_{3} \mathrm{O}_{5}:$ C, 54.72; H, 5.58; N, 13.67\%. Found: C, 54.91; H, 5.57; N, $13.79 \%$.

\section{4-(1-Morpholino-4-oxo-3-phenoxyazetidin-2-yl)benzonitrile (3k)}

White crystals (yield $35 \%$ ). mp: 198-200 ${ }^{\circ} \mathrm{C}$. IR $\left(\mathrm{KBr}, \mathrm{cm}^{-1}\right): 1767$ (CO, $\beta$-lactam), 2229 (CN). ${ }^{1} \mathrm{H}-\mathrm{NMR}\left(\mathrm{CDCl}_{3}\right) \delta 2.91\left(\mathrm{CH}_{2}-\mathrm{N}, \mathrm{m}, 2 \mathrm{H}\right), 3.06\left(\mathrm{CH}_{2}-\mathrm{N}, \mathrm{m}, 2 \mathrm{H}\right), 3.66\left(4 \mathrm{H}, \mathrm{m}, \mathrm{CH}_{2}-\mathrm{O}\right), 5.20$ $(\mathrm{H}-4, \mathrm{~d}, J=4.7 \mathrm{~Hz}, 1 \mathrm{H}), 5.32(\mathrm{H}-3, \mathrm{~d}, J=4.7 \mathrm{~Hz}, 1 \mathrm{H}), 6.66(\mathrm{ArH}, \mathrm{d}, J=8.6 \mathrm{~Hz}, 2 \mathrm{H}), 6.87(\mathrm{ArH}$, t, $J=7.2 \mathrm{~Hz}, 1 \mathrm{H}), 7.09(\mathrm{ArH}, \mathrm{t}, J=8.6 \mathrm{~Hz}, 2 \mathrm{H}), 7.55-7.62(\mathrm{ArH}, \mathrm{m}, 4 \mathrm{H}) .{ }^{13} \mathrm{C}-\mathrm{NMR}\left(\mathrm{CDCl}_{3}\right) \delta$ $53.5\left(\mathrm{CH}_{2}-\mathrm{N}\right), 62.6(\mathrm{C}-4), 66.2\left(\mathrm{CH}_{2}-\mathrm{O}\right), 79.2(\mathrm{C}-3), 112.8,115.2,118.3,122.5,129.4,129.6$, 131.9, 139.3, 153.3 (aromatic carbons and $\mathrm{CN}$ ), 164.1 (CO, $\beta$-lactam). MS m/z $=349\left[\mathrm{M}^{+}\right]$. Anal. Calcd. for $\mathrm{C}_{20} \mathrm{H}_{19} \mathrm{~N}_{3} \mathrm{O}_{3}: \mathrm{C}, 68.75 ; \mathrm{H}, 5.48 ; \mathrm{N}, 12.03 \%$. Found: C, 68.70; H, 5.57; N, $11.99 \%$. 
4-(3-(4-Chlorophenoxy)-1-morpholino-4-oxoazetidin-2-yl)benzo nitrile (3l)

White crystals (yield $29 \%$ ). mp 162-168 ${ }^{\circ} \mathrm{C}$. IR (KBr, cm $\left.{ }^{-1}\right) 1789$ (CO, $\beta$-lactam), 2229

(CN). ${ }^{1} \mathrm{H}-\mathrm{NMR}\left(\mathrm{CDCl}_{3}\right) \delta 2.90\left(\mathrm{CH}_{2}-\mathrm{N}, \mathrm{m}, 2 \mathrm{H}\right), 3.06\left(\mathrm{CH}_{2}-\mathrm{N}, \mathrm{m}, 2 \mathrm{H}\right), 3.62\left(\mathrm{CH}_{2}-\mathrm{O}, \mathrm{m}, 4 \mathrm{H}\right), 5.20$ $(\mathrm{H}-4, \mathrm{~d}, J=4.8 \mathrm{~Hz}, 1 \mathrm{H}), 5.28(\mathrm{H}-3, \mathrm{~d}, J=4.8 \mathrm{~Hz}, 1 \mathrm{H}), 6.66(\mathrm{ArH}, \mathrm{d}, J=9.0 \mathrm{~Hz}, 2 \mathrm{H}), 7.07(\mathrm{ArH}$, d, $J=9.0 \mathrm{~Hz}, 2 \mathrm{H}), 7.55(\mathrm{ArH}, \mathrm{d}, J=8.6 \mathrm{~Hz}, 2 \mathrm{H}), 7.61(\mathrm{ArH}, \mathrm{d}, J=8.6 \mathrm{~Hz}, 2 \mathrm{H}) .{ }^{13} \mathrm{C}-\mathrm{NMR}\left(\mathrm{CDCl}_{3}\right)$ $\delta 53.5\left(\mathrm{CH}_{2}-\mathrm{N}\right), 62.4(\mathrm{C}-4), 66.2\left(\mathrm{CH}_{2}-\mathrm{O}\right), 79.3(\mathrm{C}-3), 112.9,116.6,118.2,127.6,129.4,129.6$, 132.1, 139.0, 154.9 (aromatic carbons and $\mathrm{CN}$ ), 163.8 (CO, $\beta$-lactam). $\mathrm{MS} \mathrm{m} / \mathrm{z}=383$ [M+1. Anal. Calcd. for $\mathrm{C}_{20} \mathrm{H}_{18} \mathrm{ClN}_{3} \mathrm{O}_{3}: \mathrm{C}, 62.58 ; \mathrm{H}, 4.73 ; \mathrm{N}, 10.95 \%$. Found: $\mathrm{C}, 62.59 ; \mathrm{H}, 4.86 ; \mathrm{N}, 10.92 \%$.

\section{4-(1-Morpholino-3-(naphthalene-2-yloxy)-4-oxoazetidin-2-yl) benzonitrile (3m)}

White solid (yield $49 \%$ ). mp 182-184 ${ }^{\circ} \mathrm{C}$. IR (KBr, cm$\left.{ }^{-1}\right)$ 1774(CO, $\beta$-lactam), 2229 (CN). ${ }^{1} \mathrm{H}-\mathrm{NMR}\left(\mathrm{CDCl}_{3}\right) \delta 2.92\left(\mathrm{CH}_{2}-\mathrm{N}, \mathrm{m}, 4 \mathrm{H}\right), 3.67\left(\mathrm{CH}_{2}-\mathrm{O}, \mathrm{m}, 4 \mathrm{H}\right), 5.28(\mathrm{H}-4, \mathrm{~d}, J=4.7 \mathrm{~Hz}, 1 \mathrm{H})$, $5.47(\mathrm{H}-3, \mathrm{~d}, J=4.7 \mathrm{~Hz}, 1 \mathrm{H}), 6.85(\mathrm{ArH}, \mathrm{d}, J=8.9 \mathrm{~Hz}, 1 \mathrm{H}), 6.99(\mathrm{ArH}, \mathrm{s}, 1 \mathrm{H}), 7.25-7.71(\mathrm{ArH}$, m, 9H). ${ }^{13} \mathrm{C}-\mathrm{NMR}\left(\mathrm{CDCl}_{3}\right) \delta 53.5\left(\mathrm{CH}_{2}-\mathrm{N}\right), 62.6(\mathrm{C}-4), 66.2\left(\mathrm{CH}_{2}-\mathrm{O}\right), 79.2(\mathrm{C}-3), 108.7,112.8$, 117.9, 118.3, 124.5, 126.7, 126.8, 127.7, 129.6, 129.8, 131.9, 133.8, 139.3, 154.2 (aromatic carbons and $\mathrm{CN}), 164.0\left(\mathrm{CO}, \beta\right.$-lactam). MS m/z $=399\left[\mathrm{M}^{+}\right]$. Anal. Calcd. for $\mathrm{C}_{24} \mathrm{H}_{21} \mathrm{~N}_{3} \mathrm{O}_{3}: \mathrm{C}$, 72.16; H, 5.30; N, $10.52 \%$. Found: C, 72.29; H, 5.57; N, $10.59 \%$.

4-(3-Methoxy-1-morpholino-4-oxoazetidin-2-yl) benzonitrile (3n)

White crystals (yield $36 \%$ ). mp: 136-138 ${ }^{\circ} \mathrm{C}$. IR ( $\left.\mathrm{KBr}, \mathrm{cm}^{-1}\right): 1767$ (CO, $\beta$-lactam), 2230 (CN). ${ }^{1} \mathrm{H}-\mathrm{NMR}\left(\mathrm{CDCl}_{3}\right) \delta 2.86\left(\mathrm{CH}_{2}-\mathrm{N}, \mathrm{m}, 4 \mathrm{H}\right), 3.11(\mathrm{OMe}, \mathrm{s}, 3 \mathrm{H}), 3.64 .\left(\mathrm{CH}_{2}-\mathrm{O}, \mathrm{m}, 4 \mathrm{H}\right), 4.56$ $(\mathrm{H}-4, \mathrm{~d}, J=4.7 \mathrm{~Hz}, 1 \mathrm{H}), 5.03(\mathrm{H}-3, \mathrm{~d}, J=4.7 \mathrm{~Hz}, 1 \mathrm{H}), 7.59(\mathrm{ArH}, \mathrm{d}, J=8.2 \mathrm{~Hz}, 2 \mathrm{H}), 7.70(\mathrm{ArH}$, d, $J=8.2 \mathrm{~Hz}, 2 \mathrm{H}) .{ }^{13} \mathrm{C}-\mathrm{NMR}\left(\mathrm{CDCl}_{3}\right) \delta 53.4\left(\mathrm{CH}_{2}-\mathrm{N}\right), 58.5(\mathrm{OMe}), 62.1(\mathrm{C}-4), 66.2\left(\mathrm{CH}_{2}-\mathrm{O}\right)$, 83.0 (C-3), 112.6, 118.4, 129.5, 132.1, 140.0 (aromatic carbons and CN), 165.3 (CO, $\beta$-lactam). MS m/z $=287\left[\mathrm{M}^{+}\right]$. Anal. Calcd. for $\mathrm{C}_{15} \mathrm{H}_{17} \mathrm{~N}_{3} \mathrm{O}_{3}: \mathrm{C}, 62.71 ; \mathrm{H}, 5.96 ; \mathrm{N}, 14.63 \%$. Found: $\mathrm{C}, 62.79$; $\mathrm{H}, 6.07 ; \mathrm{N}, 14.69 \%$.

\section{1-Morpholino-2-(2-nitrophenyl)spiro[azetidine-3,9'-xanthen]4-one (3o)}

Light yellow solid (yield $41 \%$ ). mp 198-200 ${ }^{\circ} \mathrm{C}$. IR $\left(\mathrm{KBr}, \mathrm{cm}^{-1}\right) 1759$ (CO, $\beta$-lactam), 1346, $1523\left(\mathrm{NO}_{2}\right) .{ }^{1} \mathrm{H}-\mathrm{NMR}\left(\mathrm{CDCl}_{3}\right) \delta$ 3.52-3.76 $\left(\mathrm{CH}_{2}, \mathrm{~m}, 8 \mathrm{H}\right), 5.38(\mathrm{H}-4, \mathrm{~s}, 1 \mathrm{H}), 6.62-8.10(\mathrm{ArH}, \mathrm{m}$, 12H). ${ }^{13} \mathrm{C}-\mathrm{NMR}\left(\mathrm{CDCl}_{3}\right) \delta 53.8\left(\mathrm{CH}_{2}-\mathrm{N}\right), 61.4(\mathrm{C}-3), 66.8\left(\mathrm{CH}_{2}-\mathrm{O}\right), 73.9(\mathrm{C}-4), 114.9,116.8$, 
$116.9,120.5,122.2,123.9,124.8,125.1,127.8,128.9,129.3,129.5,131.1,133.1,147.5,152.1$, 152.3 (aromatic carbons), 169.7 (CO, $\beta$-lactam). Anal. Calcd. for $\mathrm{C}_{25} \mathrm{H}_{21} \mathrm{~N}_{3} \mathrm{O}_{5}$ : C, 67.71; $\mathrm{H}, 4.77$; N, $9.48 \%$. Found: C, 67.90; H, 4.56; N, $9.45 \%$.

\section{General procedure for the synthesis of $\beta$-lactams $5 a-h$}

Morpholine- $\beta$-lactam hybrid compounds 5a-h have been synthesized according to the introduced route in Scheme 3. A mixture of the corresponding Schiff base (4) (5.00 mmol), triethylamine (25.00 $\mathrm{mmol})$, acetic acid derivative (2) $(7.5 \mathrm{mmol})$ and $p$-toluenesulfonyl chloride (7.5 mmol) in dry $\mathrm{CH}_{2} \mathrm{Cl}_{2}(25 \mathrm{~mL})$ was stirred at room temperature overnight. After the reaction completion (TLC monitoring), the mixture was washed with $\mathrm{HCl}(1 \mathrm{~N})$, saturated sodium bicarbonate solution, brine, dried $\left(\mathrm{Na}_{2} \mathrm{SO}_{4}\right)$ and the solvent was evaporated to afford the crude $\beta$ lactams 5a-h which were purified by gel column chromatography (eluent 10:1 EtOAc/EtOH).

\section{1-(3-Morpholinopropyl)-4-(4-nitrophenyl)-3-phenoxyazetidin-2-one (5a)}

Off-white crystalline solid (yield $76 \%$ ). mp 153-155 ${ }^{\circ} \mathrm{C}$. IR $\left(\mathrm{KBr}, \mathrm{cm}^{-1}\right) 1751(\mathrm{CO}, \beta$ lactam), 1350, $1520\left(\mathrm{NO}_{2}\right) .{ }^{1} \mathrm{H}-\mathrm{NMR}\left(\mathrm{CDCl}_{3}\right) \delta 1.65$ (aliphatic chain, $\left.\mathrm{m}, 2 \mathrm{H}\right), 2.31$ (aliphatic chain and morpholine ring, m, 6H), 2.97 (aliphatic chain, m, 1H), 3.52 (aliphatic chain and morpholine ring, m, 5H), $5.05(\mathrm{H}-4, \mathrm{~d}, J=4.5 \mathrm{~Hz}, 1 \mathrm{H}), 5.48(\mathrm{H}-3, \mathrm{~d}, J=4.5 \mathrm{~Hz}, 1 \mathrm{H}), 6.67(\mathrm{ArH}, \mathrm{d}, J=8.7$ $\mathrm{Hz}, 2 \mathrm{H}), 6.83(\mathrm{ArH}, \mathrm{t}, J=7.7 \mathrm{~Hz}, 1 \mathrm{H}), 7.07(\mathrm{ArH}, \mathrm{t}, J=7.7 \mathrm{~Hz}, 2 \mathrm{H}), 7.48(\mathrm{ArH}, \mathrm{d}, J=8.7 \mathrm{~Hz}$, $2 \mathrm{H}), 8.11$ (ArH, d, $J=8.7 \mathrm{~Hz}, 2 \mathrm{H}) .{ }^{13} \mathrm{C}-\mathrm{NMR}\left(\mathrm{CDCl}_{3}\right) \delta 24.4$ (aliphatic chain), 39.2 (aliphatic chain), 53.6 (morpholine ring), 56.0 (aliphatic chain), 61.5 (C-4), 66.8 (morpholine ring), 81.9 (C3), 115.2, 122.4, 123.4, 129.3, 129.4, 141.0, 148.1, 156.4 (aromatic carbons), 165.5 (CO, $\beta$ lactam). $\mathrm{MS} \mathrm{m} / \mathrm{z}=411\left[\mathrm{M}^{+}\right]$. Anal. Calcd. for $\mathrm{C}_{22} \mathrm{H}_{25} \mathrm{~N}_{3} \mathrm{O}_{5}: \mathrm{C}, 64.22 ; \mathrm{H}, 6.12 ; \mathrm{N}, 10.21 \%$. Found: C, 64.40; H, 6.25; N, $10.17 \%$.

\section{3-(4-Chlorophenoxy)-1-(3-morpholinopropyl)-4-(4-nitrophenyl) azetidin-2-one (5b)}

Pea green solid (yield $74 \%$ ). mp 108-110 ${ }^{\circ} \mathrm{C}$. IR (KBr, cm$\left.{ }^{-1}\right) 1751$ (CO, $\beta$-lactam), 1350, $1520\left(\mathrm{NO}_{2}\right) .{ }^{1} \mathrm{H}-\mathrm{NMR}\left(\mathrm{CDCl}_{3}\right) \delta 1.68$ (aliphatic chain, $\left.\mathrm{m}, 2 \mathrm{H}\right), 2.31$ (aliphatic chain and morpholine ring, $\mathrm{m}, 6 \mathrm{H}$ ), 3.00 (aliphatic chain, $\mathrm{m}, 1 \mathrm{H}$ ), 3.54 (aliphatic chain and morpholine ring, m, 5H), $5.04(\mathrm{H}-4, \mathrm{~d}, J=4.5 \mathrm{~Hz}, 1 \mathrm{H}), 5.42(\mathrm{H}-3, \mathrm{~d}, J=4.5 \mathrm{~Hz}, 1 \mathrm{H}), 6.66$ (ArH, d, $J=8.6 \mathrm{~Hz}, 2 \mathrm{H})$, 7.07 (ArH, d, $J=8.5 \mathrm{~Hz}, 2 \mathrm{H}), 7.49(\mathrm{ArH}, \mathrm{d}, J=8.6 \mathrm{~Hz}, 2 \mathrm{H}), 8.16(\mathrm{ArH}, \mathrm{d}, J=8.5 \mathrm{~Hz}, 2 \mathrm{H}) .{ }^{13} \mathrm{C}-$ NMR $\left(\mathrm{CDCl}_{3}\right) \delta 24.4$ (aliphatic chain), 39.2 (aliphatic chain), 53.6 (morpholine ring), 56.0 
(aliphatic chain), 61.3 (C-4), 66.8 (morpholine ring), 82.0 (C-3), 116.6, 123.6, 127.5, 129.3, 129.4, 140.7, 148.2, 155.0 (aromatic carbons), 165.2 (CO, $\beta$-lactam). MS m/z $=443\left[\mathrm{M}^{+}\right]$. Anal. Calcd. for $\mathrm{C}_{22} \mathrm{H}_{24} \mathrm{ClN}_{3} \mathrm{O}_{5}$ : C, 59.26; H, 5.43; N, 9.42\%. Found: C, 59.32; H, 5.49; N, $9.39 \%$.

\section{3-(2,4-Dichlorophenoxy)-1-(3-morpholinopropyl)-4-(4-nitro phenyl)azetidin-2-one (5c)}

White solid (yield $63 \%$ ). mp 114-116 ${ }^{\circ} \mathrm{C}$. IR ( $\left.\mathrm{KBr}, \mathrm{cm}^{-1}\right) 1743$ (CO, $\beta$-lactam), 1350, 1520 $\left(\mathrm{NO}_{2}\right) .{ }^{1} \mathrm{H}-\mathrm{NMR}\left(\mathrm{CDCl}_{3}\right) \delta 1.62$ (aliphatic chain, $\mathrm{m}, 2 \mathrm{H}$ ), 2.25 (aliphatic chain and morpholine ring, $\mathrm{m}, 6 \mathrm{H}$ ), 2.97 (aliphatic chain, $\mathrm{m}, 1 \mathrm{H}$ ), 3.50 (aliphatic chain and morpholine ring, $\mathrm{m}, 5 \mathrm{H}$ ), 5.02 $(\mathrm{H}-4, \mathrm{~d}, J=4.8 \mathrm{~Hz}, 1 \mathrm{H}), 5.37(\mathrm{H}-3, \mathrm{~d}, J=4.8 \mathrm{~Hz}, 1 \mathrm{H}), 6.96(\mathrm{ArH}, \mathrm{d}, J=8.7 \mathrm{~Hz}, 1 \mathrm{H}), 7.02(\mathrm{ArH}$, d, $J=8.7 \mathrm{~Hz}, 1 \mathrm{H}), 7.13(\mathrm{ArH}, \mathrm{s}, 1 \mathrm{H}), 7.48(\mathrm{ArH}, \mathrm{d}, J=8.7 \mathrm{~Hz}, 2 \mathrm{H}), 8.15(\mathrm{ArH}, \mathrm{d}, J=8.7 \mathrm{~Hz}$, 2H). ${ }^{13} \mathrm{C}-\mathrm{NMR}\left(\mathrm{CDCl}_{3}\right) \delta 24.4$ (aliphatic chain), 39.3 (aliphatic chain), 53.6 (morpholine ring), 56.0 (aliphatic chain), 60.9 (C-4), 66.8 (morpholine ring), 82.5 (C-3), 116.4, 123.6, 123.9, 127.6, 127.8, 129.4, 130.1, 140.6, 148.3, 151.2 (aromatic carbons), 164.9 (CO, $\beta$-lactam). MS m/z = 480 $\left[\mathrm{M}^{+}\right]$. Anal. Calcd. for $\mathrm{C}_{22} \mathrm{H}_{23} \mathrm{Cl}_{2} \mathrm{~N}_{3} \mathrm{O}_{5}: \mathrm{C}, 55.01 ; \mathrm{H}, 4.83 ; \mathrm{N}, 8.75 \%$. Found: $\mathrm{C}, 55.15 ; \mathrm{H}, 4.97 ; \mathrm{N}$, $8.71 \%$.

\section{1-(3-Morpholinopropyl)-3-(naphthalen-2-yloxy)-4-(4-nitro phenyl)azetidin-2-one (5d)}

Pea green solid (yield $79 \%$ ). mp 133-135 ${ }^{\circ} \mathrm{C}$. IR (KBr, cm $\left.{ }^{-1}\right) 1751$ (CO, $\beta$-lactam), 1350, $1520\left(\mathrm{NO}_{2}\right) .{ }^{1} \mathrm{H}-\mathrm{NMR}\left(\mathrm{CDCl}_{3}\right) \delta 1.69$ (aliphatic chain, $\left.\mathrm{m}, 2 \mathrm{H}\right), 2.29$ (aliphatic chain and morpholine ring, $\mathrm{m}, 6 \mathrm{H}$ ), 3.00 (aliphatic chain, $1 \mathrm{H}, \mathrm{m}$ ), 3.57 (aliphatic chain and morpholine ring, $5 \mathrm{H}, \mathrm{m}), 5.15(\mathrm{H}-4, \mathrm{~d}, J=4.4 \mathrm{~Hz}, 1 \mathrm{H}), 5.64(\mathrm{H}-3, \mathrm{~d}, J=4.4 \mathrm{~Hz}, 1 \mathrm{H}), 6.84(\mathrm{ArH}, \mathrm{d}, J=8.9 \mathrm{~Hz}, 1 \mathrm{H})$, 7.06 (ArH, s, 1H), 6.26-7.69 (ArH, m, 7H), $8.10(\mathrm{ArH}, \mathrm{d}, J=8.7 \mathrm{~Hz}, 2 \mathrm{H}) .{ }^{13} \mathrm{C}-\mathrm{NMR}\left(\mathrm{CDCl}_{3}\right) \delta$ 24.5 (aliphatic chain), 39.2 (aliphatic chain), 53.6 (morpholine ring), 56.0 (aliphatic chain 61.5 (C4), 66.8 (morpholine ring), 81.9 (C-3), 108.7, 118.0, 123.5, 124.4, 126.6, 126.8, 127.7, 129.3, 129.6, 129.7, 133.8, 140.9, 148.1, 154.3 (aromatic carbons), 165.4 (CO, $\beta$-lactam). MS m/z = 461 $\left[\mathrm{M}^{+}\right]$; Anal. Calcd. for $\mathrm{C}_{26} \mathrm{H}_{27} \mathrm{~N}_{3} \mathrm{O}_{5}: \mathrm{C}, 67.66 ; \mathrm{H}, 5.90 ; \mathrm{N}, 9.10 \%$. Found: $\mathrm{C}, 67.54 ; \mathrm{H}, 6.02 ; \mathrm{N}$, $9.13 \%$.

\section{1-(3-Morpholinopropyl)-4-(3-nitrophenyl)-3-phenoxyazetidin-2-one (5e)}

White solid (yield $69 \%$ ). mp 101-103 ${ }^{\circ} \mathrm{C}$. IR ( $\left.\mathrm{KBr}, \mathrm{cm}^{-1}\right) 1751$ (CO, $\beta$-lactam), 1350, 1527

$\left(\mathrm{NO}_{2}\right) .{ }^{1} \mathrm{H}-\mathrm{NMR}\left(\mathrm{CDCl}_{3}\right) \delta 1.64$ (aliphatic chain, $\mathrm{m}, 2 \mathrm{H}$ ), 2.28 (aliphatic chain and morpholine 
ring, $\mathrm{m}, 6 \mathrm{H}$ ), 2.97 (aliphatic chain, $\mathrm{m}, 1 \mathrm{H}$ ), 3.51 (aliphatic chain and morpholine ring, $\mathrm{m}, 5 \mathrm{H}$ ), 5.00 $(\mathrm{H}-4, \mathrm{~d}, J=4.4 \mathrm{~Hz}, 1 \mathrm{H}), 5.43(\mathrm{H}-3, \mathrm{~d}, J=4.4 \mathrm{~Hz}, 1 \mathrm{H}), 6.62(\mathrm{ArH}, \mathrm{d}, J=7.9 \mathrm{~Hz}, 2 \mathrm{H}), 6.81(\mathrm{ArH}$, $\mathrm{t}, J=7.5 \mathrm{~Hz}, 1 \mathrm{H}), 7.02(\mathrm{ArH}, \mathrm{t}, J=7.9 \mathrm{~Hz}, 2 \mathrm{H}), 7.40(\mathrm{ArH}, \mathrm{t}, 1 \mathrm{H}), 7.62(\mathrm{ArH}, \mathrm{d}, J=7.8 \mathrm{~Hz}, 1 \mathrm{H})$, $8.05(\mathrm{ArH}, \mathrm{d}, J=8.1 \mathrm{~Hz}, 1 \mathrm{H}), 8.12(\mathrm{ArH}, \mathrm{s}, 1 \mathrm{H}) .{ }^{13} \mathrm{C}-\mathrm{NMR}\left(\mathrm{CDCl}_{3}\right) \delta 24.4$ (aliphatic chain), 39.1 (aliphatic chain), 53.6 (morpholine ring), 56.0 (aliphatic chain), 61.5 (C-4), 66.7 (morpholine ring), 81.7 (C-3), 115.2, 122.4, 123.5, 123.8, 129.3, 129.4, 134.3, 135.8, 148.1, 156.3 (aromatic carbons), 165.5 (CO, $\beta$-lactam). MS m/z $=411\left[\mathrm{M}^{+}\right]$. Anal. Calcd. for $\mathrm{C}_{22} \mathrm{H}_{25} \mathrm{~N}_{3} \mathrm{O}_{5}: \mathrm{C}, 64.22 ; \mathrm{H}, 6.12 ; \mathrm{N}$, 10.21\%. Found: C, 64.37; H, 6.20; N, $10.16 \%$.

\section{1-(3-Morpholinopropyl)-3-(naphthalen-2-yloxy)-4-(3-nitro phenyl) azetidin-2-one (5f)}

Off white crystals (yield $63 \%$ ). mp: $126-128{ }^{\circ} \mathrm{C}$. IR $\left(\mathrm{KBr}, \mathrm{cm}^{-1}\right): 1759$ (CO, $\beta$-lactam), 1350, $1527\left(\mathrm{NO}_{2}\right) .{ }^{1} \mathrm{H}-\mathrm{NMR}\left(\mathrm{CDCl}_{3}\right) \delta .64(\mathrm{H}-3, \mathrm{~d}, J=4.4 \mathrm{~Hz}, 1 \mathrm{H}), 6.88(\mathrm{ArH}, \mathrm{d}, J=8.9 \mathrm{~Hz}, 1 \mathrm{H})$, 7.07 (ArH, s, 1H), 7.31-8.24 (ArH, m, 7H), 8.23 (ArH, d, J=8.7 Hz, 1H), 8.57 (ArH, s, 1H). ${ }^{13} \mathrm{C}-$

NMR $\left(\mathrm{CDCl}_{3}\right) \delta 24.4$ (aliphatic chain), 39.2 (aliphatic chain), 53.5 (morpholine ring), 56.0 (aliphatic chain), 61.4 (C-4), 66.7 (morpholine ring), 81.7 (C-3), 108.8, 117.9, 123.4, 123.8, 124.4, 126.6, 126., 127.6, 129.3, 129.5, 129.7, 133.8, 134.4, 135.8, 148.1, 154.2 (aromatic carbons), 165.5 (CO, $\beta$-lactam). $\mathrm{MS} \mathrm{m} / \mathrm{z}=461\left[\mathrm{M}^{+}\right]$. Anal. Calcd. for $\mathrm{C}_{26} \mathrm{H}_{27} \mathrm{~N}_{3} \mathrm{O}_{5}: \mathrm{C}, 67.66 ; \mathrm{H}, 5.90 ; \mathrm{N}, 9.10 \%$. Found: C, 67.74; H, 6.02; N, $9.13 \%$.

\section{1-(3-Morpholinopropyl)-2-(4-nitrophenyl)spiro[azetidine-3,9'-xanthen]-4-one (5g)}

White solid (yield $71 \%$ ). mp 160-162 ${ }^{\circ} \mathrm{C}$. IR (KBr, $\left.\mathrm{cm}^{-1}\right) 1743$ (CO, $\beta$-lactam), 1350, 1527 $\left(\mathrm{NO}_{2}\right) .{ }^{1} \mathrm{H}-\mathrm{NMR}\left(\mathrm{CDCl}_{3}\right) \delta 1.93$ (aliphatic chain, $\left.\mathrm{m}, 2 \mathrm{H}\right), 2.44$ (aliphatic chain and morpholine ring, 6H, m), 3.17 (aliphatic chain, m, 1H), 3.66 (morpholine ring, m, 4H), 3.96 (aliphatic chain, 1H, m), $4.73(\mathrm{H}-4, \mathrm{~s}, 1 \mathrm{H}), 6.82-7.43(\mathrm{ArH}, 10 \mathrm{H}, \mathrm{m}), 7.95$ (ArH, d, J = 8.7 Hz, 2H). ${ }^{13} \mathrm{C}-\mathrm{NMR}$ $\left(\mathrm{CDCl}_{3}\right) \delta 25.0$ (aliphatic chain), 39.9 (aliphatic chain), 53.6 (morpholine ring), 56.0 (aliphatic chain), 65.4 (C-3), 66.8 (morpholine ring), 73.7 (C-4), 116.5, 116.7, 117.1, 121.2, 122.9, 123.4, 124.4, 125.1, 127.3, 127.7, 129.4, 129.5, 142.2, 147.3, 151.9, 152.1(aromatic carbons), 168.0 (CO, $\beta$-lactam). MS m/z $=485\left[\mathrm{M}^{+}\right]$; Anal. Calcd. for $\mathrm{C}_{28} \mathrm{H}_{27} \mathrm{~N}_{3} \mathrm{O}_{5}: \mathrm{C}, 69.26 ; \mathrm{H}, 5.61 ; \mathrm{N}, 8.65 \%$. Found: C, 69.37; H, 5.74; N, $8.67 \%$. 


\section{1-(3-Morpholinopropyl)-2-(3-nitrophenyl)spiro[azetidine-3,9'-xanthen]-4-one (5h)}

Light yellow crystalline solid (yield $59 \%)$. mp $151-153{ }^{\circ} \mathrm{C}$. IR $\left(\mathrm{KBr}, \mathrm{cm}^{-1}\right) 1751$ (CO, $\beta$ lactam), 1342, $1527\left(\mathrm{NO}_{2}\right) .{ }^{1} \mathrm{H}-\mathrm{NMR}\left(\mathrm{CDCl}_{3}\right) \delta 1.94$ (aliphatic chain, $\left.\mathrm{m}, 2 \mathrm{H}\right), 2.49$ (aliphatic chain and morpholine ring, $\mathrm{m}, 6 \mathrm{H}$ ), 3.18 (aliphatic chain, m, 1H), 3.68 (morpholine ring, $\mathrm{m}, 4 \mathrm{H}$ ), 3.94 (aliphatic chain, m, 1H), $4.72(\mathrm{H}-4, \mathrm{~s}, 1 \mathrm{H}), 6.79-7.94(\mathrm{ArH}, \mathrm{m}, 12 \mathrm{H}),{ }^{13} \mathrm{C}-\mathrm{NMR}\left(\mathrm{CDCl}_{3}\right) \delta 24.9$ (aliphatic chain), 39.9 (aliphatic chain), 53.5 (morpholine ring), 56.0 (aliphatic chain), 65.2 (C-3), 66.6 (morpholine ring), 73.4 (C-4), 116.4, 116.8, 117.1, 121.2, 121.3, 122.9, 123.0, 124.4, 125.1, 127.8, 129.3, 129.4, 129.4, 132.6, 136.9, 147.9, 151.9, 152.1 (aromatic carbons), 168.1 (CO, $\beta$ lactam). MS m/z $=485\left[\mathrm{M}^{+}\right]$. Anal. Calcd. for $\mathrm{C}_{28} \mathrm{H}_{27} \mathrm{~N}_{3} \mathrm{O}_{5}$ : C, 69.26; $\mathrm{H}, 5.61 ; \mathrm{N}, 8.65 \%$. Found: C, 69.30; H, 5.69; N, $8.67 \%$.

\section{General Procedure for the Synthesis of Monocyclic $\beta$-Lactams 6a-f:}

$\beta$-Lactams 5a-f $(1 \mathrm{mmol})$ were dissolved in $80 \mathrm{~mL}$ of EtOH: $\mathrm{H}_{2} \mathrm{O}$ (9:1) by heating to reflux. Then the temperature was reduced to $60{ }^{\circ} \mathrm{C}$ and an $80 \%$ aqueous solution of hydrazine hydrate $(0.15 \mathrm{~mL}, 2.3 \mathrm{mmol})$ and Raney-Ni ( $1 \mathrm{~g}$ as aqueous slurry) were added. The mixture was refluxed for an appropriate time for complete conversion by TLC monitoring. The mixture was cooled to room temperature and then filtered through a pad of Celite. The solvent was evaporated under reduced pressure and purified by silica gel chromatography (eluent 5:1 EtOAc/EtOH) to yield pure $\beta$-lactams 6a-f.

\section{4-(4-Aminophenyl)-1-(3-morpholinopropyl)-3-phenoxyazetidin-2-one (6a)}

White solid (yield $96 \%$ ). mp 136-138 ${ }^{\circ} \mathrm{C}$. IR ( $\left.\mathrm{KBr}, \mathrm{cm}^{-1}\right) 1751$ (CO, $\beta$-lactam), 3356, 3456 $\left(\mathrm{NH}_{2}\right) .{ }^{1} \mathrm{H}-\mathrm{NMR}\left(\mathrm{CDCl}_{3}\right) \delta 1.62$ (aliphatic chain, $\mathrm{m}, 2 \mathrm{H}$ ), 2.29 (aliphatic chain and morpholine ring, $\mathrm{m}, 6 \mathrm{H}$ ), 2.95 (aliphatic chain, $\mathrm{m}, 1 \mathrm{H}$ ), 3.43(aliphatic chain, $\mathrm{m}, 1 \mathrm{H}$ ), 3.65 (morpholine ring and $\left.\mathrm{NH}_{2}, \mathrm{~m}, 6 \mathrm{H}\right), 4.81(\mathrm{H}-4, \mathrm{~d}, J=4.3 \mathrm{~Hz}, 1 \mathrm{H}), 5.34(\mathrm{H}-3, \mathrm{~d}, J=4.3 \mathrm{~Hz}, 1 \mathrm{H}), 6.55(\mathrm{ArH}, \mathrm{d}, J=$ $8.4 \mathrm{~Hz}, 2 \mathrm{H}), 6.72(\mathrm{ArH}, \mathrm{d}, J=8.4 \mathrm{~Hz}, 2 \mathrm{H}), 6.83(\mathrm{ArH}, \mathrm{t}, J=7.3 \mathrm{~Hz}, 1 \mathrm{H}), 7.08(\mathrm{ArH}, \mathrm{d}, J=8.3$ $\mathrm{Hz}, 2 \mathrm{H}), 7.14(\mathrm{ArH}, \mathrm{t}, J=8.6 \mathrm{~Hz}, 2 \mathrm{H}) .{ }^{13} \mathrm{C}-\mathrm{NMR}\left(\mathrm{CDCl}_{3}\right) \delta 24.4$ (aliphatic chain), 38.4 (aliphatic chain), 53.6 (morpholine ring), 56.2 (aliphatic chain), 62.2 (C-4), 66.9 (morpholine ring), 81.9 (C3), 114.7, 115.6, 121.8, 122.2, 129.1, 129.8, 146.9, 157.0 (aromatic carbons), 166.1 (CO, $\beta$ lactam). MS m/z $=382\left[\mathrm{M}^{+}\right]$. Anal. Calcd. for $\mathrm{C}_{22} \mathrm{H}_{27} \mathrm{~N}_{3} \mathrm{O}_{3}: \mathrm{C}, 69.27 ; \mathrm{H}, 7.13 ; \mathrm{N}, 11.02 \%$. Found: C, 69.35; H, 7.15; N, $10.95 \%$. 
4-(4-Aminophenyl)-3-(4-chlorophenoxy)-1-(3-morpholinopropyl) azetidin-2-one (6b)

White solid (yield $92 \%$ ). mp 177-180 ${ }^{\circ} \mathrm{C}$. IR (KBr, cm ${ }^{-1}$ ) 1735 (CO, $\beta$-lactam), 3332, 3409 $\left(\mathrm{NH}_{2}\right) .{ }^{1} \mathrm{H}-\mathrm{NMR}\left(\mathrm{CDCl}_{3}\right) \delta 1.56$ (aliphatic chain, m, 2H), 2.23 (aliphatic chain and morpholine ring, m, 6H), 2.89 (aliphatic chain, m, 1H), 3.36 (aliphatic chain, m, 1H), 3.59 (morpholine ring and $\left.\mathrm{NH}_{2}, \mathrm{~m}, 6 \mathrm{H}\right), 4.74(\mathrm{H}-4, \mathrm{~d}, J=4.3 \mathrm{~Hz}, 1 \mathrm{H}), 5.23(\mathrm{H}-3, \mathrm{~d}, J=4.3 \mathrm{~Hz}, 1 \mathrm{H}), 6.50$ (ArH, d, $J=$ $8.4 \mathrm{~Hz}, 2 \mathrm{H}), 6.59$ (ArH, d, $J=9.0 \mathrm{~Hz}, 2 \mathrm{H}), 6.97$ (ArH, d, $J=8.4 \mathrm{~Hz}, 2 \mathrm{H}), 6.99$ (ArH, d, $J=9.0$ $\mathrm{Hz}, 2 \mathrm{H}) .{ }^{13} \mathrm{C}-\mathrm{NMR}\left(\mathrm{CDCl}_{3}\right) \delta 24.4$ (aliphatic chain), 38.5 (aliphatic chain), 53.6 (morpholine ring), 56.2 (aliphatic chain), 62.0 (C-4), 66.9 (morpholine ring), 81.9 (C-3), 114.7, 116.8, 121.9, 126.8, 129.1, 129.8, 147.0, 155.6 (aromatic carbons), 165.7 (CO, $\beta$-lactam). MS m/z = 416 [M+ ${ }^{+}$. Anal. Calcd. for $\mathrm{C}_{22} \mathrm{H}_{26} \mathrm{ClN}_{3} \mathrm{O}_{3}$ : C, 63.53; H, 6.30; N, 10.10\%. Found: C, 63.67; H, 6.41; N, $10.06 \%$.

\section{4-(4-Aminophenyl)-3-(2,4-dichlorophenoxy)-1-(3-morpholino propyl)azetidin-2-one (6c)}

White solid (yield $67 \%$ ). mp 132-134 ${ }^{\circ} \mathrm{C}$. IR (KBr, cm $\left.{ }^{-1}\right) 1743$ (CO, $\beta$-lactam), 3332, 3409 $\left(\mathrm{NH}_{2}\right) .{ }^{1} \mathrm{H}-\mathrm{NMR}\left(\mathrm{CDCl}_{3}\right) \delta 1.63$ (aliphatic chain, m, 2H), 2.29 (aliphatic chain and morpholine ring, m, 6H), 2.94 (aliphatic chain, m, 1H), 3.34 (aliphatic chain, m, 1H), 3.62 (morpholine ring and $\left.\mathrm{NH}_{2}, \mathrm{~m}, 6 \mathrm{H}\right), 4.79(\mathrm{H}-4, \mathrm{~d}, J=4.4 \mathrm{~Hz}, 1 \mathrm{H}), 5.28(\mathrm{H}-3, \mathrm{~d}, J=4.4 \mathrm{~Hz}, 1 \mathrm{H}), 6.52(\mathrm{ArH}, \mathrm{d}, J=$ $8.2 \mathrm{~Hz}, 2 \mathrm{H}), 6.74(\mathrm{ArH}, \mathrm{d}, J=8.8 \mathrm{~Hz}, 1 \mathrm{H}), 6.95(\mathrm{ArH}, \mathrm{d}, J=8.8 \mathrm{~Hz}, 1 \mathrm{H}), 7.03(\mathrm{ArH}, \mathrm{d}, J=8.2$ $\mathrm{Hz}, 2 \mathrm{H}), 7.13(\mathrm{ArH}, \mathrm{s}, 1 \mathrm{H}) .{ }^{13} \mathrm{C}-\mathrm{NMR}\left(\mathrm{CDCl}_{3}\right) \delta 24.1$ (aliphatic chain), 38.4 (aliphatic chain), 53.4 (morpholine ring), 56.0 (aliphatic chain), 61.6 (C-4), 66.5 (morpholine ring), 82.1 (C-3), 114.7, $115.9,121.5,123.9,126.9,127.2,129.4,129.9,147.2,151.4$ (aromatic carbons), 165.3 (CO, $\beta$ lactam). $\mathrm{MS} \mathrm{m} / \mathrm{z}=450\left[\mathrm{M}^{+}\right]$. Anal. Calcd. for $\mathrm{C}_{22} \mathrm{H}_{25} \mathrm{Cl}_{2} \mathrm{~N}_{3} \mathrm{O}_{3}: \mathrm{C}, 58.67 ; \mathrm{H}, 5.60 ; \mathrm{N}, 9.33 \%$. Found: C, 58.72; H, 5.73; N, 9.37\%.

\section{4-(4-Aminophenyl)-1-(3-morpholinopropyl)-3-(naphthalene-2-yloxy)azetidin-2-one (6d)}

White solid (yield $79 \%$ ). mp 152-154 ${ }^{\circ} \mathrm{C}$. IR (KBr, cm $\left.{ }^{-1}\right) 1737$ (CO, $\beta$-lactam), 3338, 3430 $\left(\mathrm{NH}_{2}\right) .{ }^{1} \mathrm{H}-\mathrm{NMR}\left(\mathrm{CDCl}_{3}\right) \delta 1.71$ (aliphatic chain, m, 2H), 2.42 (aliphatic chain and morpholine ring, m, 6H), 2.99 (aliphatic chain, $\mathrm{m}, 1 \mathrm{H}$ ), 3.46 (aliphatic chain, morpholine ring and $\mathrm{NH}_{2}, \mathrm{~m}$, 7H), $4.93(\mathrm{H}-4, \mathrm{~d}, J=4.0 \mathrm{~Hz}, 1 \mathrm{H}), 5.50(\mathrm{H}-3, \mathrm{~d}, J=4.0 \mathrm{~Hz}, 1 \mathrm{H}), 6.53(\mathrm{ArH}, \mathrm{d}, J=8.1 \mathrm{~Hz}, 2 \mathrm{H})$, $6.95(\mathrm{ArH}, \mathrm{d}, J=8.6 \mathrm{~Hz}, 1 \mathrm{H}), 7.03(\mathrm{ArH}, \mathrm{S}, 1 \mathrm{H}), 7.12(\mathrm{ArH}, \mathrm{d}, J=8.1 \mathrm{~Hz}, 2 \mathrm{H}), 7.26-7.69(\mathrm{ArH}$, $\mathrm{m}, 5 \mathrm{H}) .{ }^{13} \mathrm{C}-\mathrm{NMR}\left(\mathrm{CDCl}_{3}\right) \delta 24.4$ (aliphatic chain), 38.5 (aliphatic chain), 53.6 (morpholine ring), 
56.2 (aliphatic chain), 62.2 (C-4), 66.8 (morpholine ring), 81.8 (C-3), 108.9, 114.8, 118.5, 122.1, 124.0, 126.3, 126.8, 127.6, 129.3, 129.4, 129.8, 133.9, 146.9, 154.9 (aromatic carbons), 166.0 (CO, $\beta$-lactam). MS m/z $=431\left[\mathrm{M}^{+}\right]$. Anal. Calcd. for $\mathrm{C}_{26} \mathrm{H}_{29} \mathrm{~N}_{3} \mathrm{O}_{3}: \mathrm{C}, 72.37 ; \mathrm{H}, 6.77 ; \mathrm{N}, 9.74 \%$. Found: C, 72.45; H, 6.89; N, $9.69 \%$.

\section{4-(3-Aminophenyl)-1-(3-morpholinopropyl)-3-phenoxyazetidin-2-one (6e)}

Off-white solid (yield $68 \%$ ). mp 117-119 ${ }^{\circ} \mathrm{C}$. IR (KBr, $\mathrm{cm}^{-1}$ ) 1751 (CO, $\beta$-lactam), 3356, $3456\left(\mathrm{NH}_{2}\right) .{ }^{1} \mathrm{H}-\mathrm{NMR}\left(\mathrm{CDCl}_{3}\right) \delta 1.62$ (aliphatic chain, $\left.\mathrm{m}, 2 \mathrm{H}\right), 2.25$ (aliphatic chain and morpholine ring, m, 6H), 2.95 (aliphatic chain, m, 1H), 3.47 (aliphatic chain, m, 1H), 3.63 (morpholine ring and $\left.\mathrm{NH}_{2}, \mathrm{~m}, 6 \mathrm{H}\right), 4.79(\mathrm{H}-4, \mathrm{~d}, J=4.4 \mathrm{~Hz}, 1 \mathrm{H}), 5.35(\mathrm{H}-3, \mathrm{~d}, J=4.4 \mathrm{~Hz}, 1 \mathrm{H})$, $6.56(\mathrm{ArH}, \mathrm{d}, J=7.7 \mathrm{~Hz}, 1 \mathrm{H}), 6.60(\mathrm{ArH}, \mathrm{d}, J=8.3 \mathrm{~Hz}, 1 \mathrm{H}), 6.66(\mathrm{ArH}, \mathrm{s}, 1 \mathrm{H}), 6.72$ (ArH, d, $J=$ $8.5 \mathrm{~Hz}, 2 \mathrm{H}), 6.99$ (ArH, t, $J=7.7 \mathrm{~Hz}, 1 \mathrm{H}), 7.07$ (ArH, t, $J=8.5 \mathrm{~Hz}, 1 \mathrm{H}), 7.11$ (ArH, t, $J=7.5 \mathrm{~Hz}$, 2H). ${ }^{13} \mathrm{C}-\mathrm{NMR}\left(\mathrm{CDCl}_{3}\right) \delta 24.4$ (aliphatic chain), 38.6 (aliphatic chain), 53.6 (morpholine ring), 56.2 (aliphatic chain), 62.3 (C-4), 66.9 (morpholine ring), 81.9 (C-3), 114.7, 115.4, 115.7, 118.9, $121.9,129.1,129.2,134.2,146.5,157.1$ (aromatic carbons), 166.1 (CO, $\beta$-lactam). MS m/z = 382 $\left[\mathrm{M}^{+}\right]$. Anal. Calcd. for $\mathrm{C}_{22} \mathrm{H}_{27} \mathrm{~N}_{3} \mathrm{O}_{3}$ : C, 69.27; H, 7.13; N, 11.02\%. Found: C, 69.45; H, 7.25; N, $10.95 \%$.

\section{4-(3-Aminophenyl)-1-(3-morpholinopropyl)-3-(naphthalene-2-yloxy)azetidin-2-one (6f)}

White solid purified by column chromatography (eluent 5:1 EtOAc/EtOH) (yield 59\%). mp 133-135 ${ }^{\circ} \mathrm{C}$. IR (KBr, cm $\left.{ }^{-1}\right) 1751$ (CO, $\beta$-lactam), 3348, $3440\left(\mathrm{NH}_{2}\right) .{ }^{1} \mathrm{H}-\mathrm{NMR}\left(\mathrm{CDCl}_{3}\right) \delta 1.67$ (aliphatic chain, $\mathrm{m}, 2 \mathrm{H}$ ), 2.34 (aliphatic chain and morpholine ring, $\mathrm{m}, 6 \mathrm{H}$ ), 3.02 (aliphatic chain, $\mathrm{m}, 1 \mathrm{H}$ ), 3.50 (aliphatic chain, morpholine ring and $\left.\mathrm{NH}_{2}, \mathrm{~m}, 7 \mathrm{H}\right), 4.90(\mathrm{H}-4, \mathrm{~d}, J=4.3 \mathrm{~Hz}, 1 \mathrm{H})$, $5.52(\mathrm{H}-3, \mathrm{~d}, J=4.3 \mathrm{~Hz}, 1 \mathrm{H}), 6.50(\mathrm{ArH}, \mathrm{d}, J=7.9 \mathrm{~Hz}, 1 \mathrm{H}), 6.65-7.69$ (ArH, m, 10H). ${ }^{13} \mathrm{C}-\mathrm{NMR}$ $\left(\mathrm{CDCl}_{3}\right) \delta 24.3$ (aliphatic chain), 38.7 (aliphatic chain), 53.5 (morpholine ring), 56.1 (aliphatic chain), 62.3 (C-4), 66.7 (morpholine ring), 81.9 (C-3), 109.3, 114.7, 115.5, 118.6, 118.9, 124.1, 126.4, 126.9, 127.6, 129.2, 129.3, 129.5, 133.9, 134.2, 146.5, 154.9 (aromatic carbons), 166.0 (CO, $\beta$-lactam). MS m/z=431 [M+ $\mathrm{M}^{+}$. Anal. Calcd. for $\mathrm{C}_{26} \mathrm{H}_{29} \mathrm{~N}_{3} \mathrm{O}_{3}: \mathrm{C}, 72.37 ; \mathrm{H}, 6.77 ; \mathrm{N}, 9.74 \%$. Found: C, 72.55; H, 6.85; N, $9.69 \%$. 


\section{In vitro anti-inflammatory activity [42]}

\section{Principle of the assay}

The in vitro anti-inflammatory assay is based on the ability of macrophages to generate a strong inflammatory response when stimulated with antigens. Mouse immortalized macrophages (RAW 264.7 cell line) are stimulated by E. coli LPS and exposed to the test material for 24 hours. At the end of the incubation period, NO production is evaluated indirectly by measuring the accumulation of nitrite/nitrate, the stable end-products of NO oxidation, in the culture medium using a spectrophotometric method based on the Griess reaction. [42]

\section{Cell line}

Mouse macrophages (RAW 264.7, Sigma-Aldrich, N P6110401, Lot. 09I006), low passage number $(<50)$.

\section{Culture medium}

Complete medium: DMEM with L-glutamine (Dulbecco's Minimum Essential Medium, Pan Biotech Lot 974251) supplemented with penicillin-streptomycin (10,000 U/mL penicillin, 10 $\mathrm{mg} / \mathrm{mL}$ streptomycin, Pan Biotech, Lot 20145123), and 10\% inactivated calf serum (Pan Biotech, Lot P440008), pH 7.2, freshly prepared, stored no longer than 3 weeks.

\section{Dilutions of the test material}

The test materials were diluted into dimethylsulfoxide (DMSO, Sigma-Aldrich) at the final concentration of $10 \mathrm{mM}$.

\section{Controls}

Negative control: DMSO

Positive control: Dexamethasone at 1, 5, 10, 50, and $100 \mu \mathrm{M}$ in DMSO

\section{Test procedure}

Cells were seeded into 48 -well tissue culture plates at the concentration of $1 \times 10^{5}$ cells $/ \mathrm{mL}(200$ $\mu \mathrm{l} /$ well) for 24 hours at $37^{\circ} \mathrm{C}\left(5 \% \mathrm{CO}_{2}\right)$. At the end of the incubation period the culture medium was replaced by $200 \mu \mathrm{L}$ of medium containing the appropriate concentrations of the test materials, and cells were incubated at $37^{\circ} \mathrm{C}\left(5 \% \mathrm{CO}_{2}\right)$ for one hour. At the end of the incubation period, proinflammatory LPS from $E$. coli was added to the cell cultures $(1 \mu \mathrm{g} / \mathrm{mL})$. The cells were then incubated at $37^{\circ} \mathrm{C}\left(5 \% \mathrm{CO}_{2}\right)$ for 24 hours. 


\section{Assessment of NO release}

NO release was measured in the culture supernatant by the Griess reaction. $100 \mu 1$ of the supernatants were transferred into the wells of a 96-well tissue culture plate, and $100 \mu 1$ of the Griess modified reagent (Sigma-Aldrich) were added in each well. After a 15 min period at room temperature, the Optical Density (OD) of each well was read at $540 \mathrm{~nm}$ by a fluorescenceluminescence reader Infinite M200 Pro (Tecan). The results obtained for wells treated with the test material were compared to those of untreated control wells (DMSO, 100\% viability) and converted to percentage values.

\section{Assessment of cell viability}

In parallel to the assessment of NO release, cell viability was measured to validate the assay. The WST-1 vital dye reagent was used to measure cell mitochondrial respiration. For this purpose, the culture medium was decanted and $100 \mu \mathrm{l}$ of WST-1 reagent (1/10 dilution) were added in each well. After a 30-min incubation period at $37^{\circ} \mathrm{C}(5 \% \mathrm{CO} 2)$, the Optical Density (OD) of each well was read at $450 \mathrm{~nm}$ by a fluorescence-luminescence reader Infinite M200 Pro (TECAN). The results obtained for wells treated with the test material were compared to those of untreated control wells (DMSO, 100\% viability) and converted to percentage values.

\section{Calculation of the $\mathrm{IC}_{50}$}

Inhibition of NO release and inhibition of cell viability were expressed as percentages as compared to the negative controls:

$$
\begin{aligned}
& \text { Percentage of NO release }=\frac{100 \times(\text { OD of test well }- \text { OD of blank })}{\text { OD of DMSO control }- \text { OD of blank }} \\
& \text { Percentage of Cell viabilty }=\frac{100 \times(\text { OD of test well }- \text { OD of blank })}{\text { OD of DMSO control }- \text { OD of blank }}
\end{aligned}
$$

The concentrations of the test material causing respectively a $50 \%$ decrease of NO release $\left(\mathrm{IC}_{50}\right.$ NO release) and a $50 \%$ decrease of cell viability ( $\left.\mathrm{IC}_{50 \text {-cell viability }}\right)$ were calculated using software Tablecurve Version 2.0. The anti-inflammatory ratio corresponded to the ratio between the antiinflammatory activity and the toxicity, and expressed as follows: 
Anti-inflammatory ratio $=\mathrm{IC}_{50 \text {-cell viability }} / \mathrm{IC}_{50-\mathrm{NO}}$ release

\section{Molecular docking studies}

Computer-simulated docking studies were accomplished by the AutoDock 4.2 software. [43] Lamarckian Genetic Algorithm of the AutoDock 4.2 program was used as the search algorithm. The Graphical User Interface program AutoDock Tools 1.5.6 (ADT) were used to prepare, run, and analyze the docking simulations. Molecular docking of compounds was performed with the published crystal structure (PDB ID: 4NOS (human inducible nitric oxide synthase)) by the Auto-Dock Tool 1.5.6. All two dimensional (2D) structures of the compounds were built using the ChemDraw program (ChemDraw Ultra 10.0, Cambridge soft.), and then moved into the Hyperchem 8.0 software (HyperChem, Release 8.0 for Windows, Molecular Modeling System: HyperCube, 2007). Molecules were subjected to energy minimization with $\mathrm{MM}^{+}$force field and then PM3 semi-empirical technique. Then the partial charges of atoms were calculated by the GasteigereMarsili procedure implemented in the AutoDock Tools package. The non-polar hydrogens of compounds were merged. The crystal structure of protein was taken from Protein Data bank (www. rcsb.org). All bound water and ligands were eliminated from the protein, and polar hydrogen atom were added to the protein as it was required for the electrostatics interactions, and then non-polar hydrogen atoms were merged together. In all dockings, a grid map with 60 grid points in the $\mathrm{X}, \mathrm{Y}$, and $\mathrm{Z}$ directions was built. Among the three different search algorithms offered by AutoDock 4.2, the Lamarckian genetic algorithm (LGA) approach was applied. For all docking procedures, 150 independent runs with the step sizes of $0.2 \AA$ for translations and $5^{\circ}$ for orientations and torsions were considered. For the Lamarckian GA method, a maximum number of $25 \times 10^{5}$ energy evaluations; 27,000 maximum generations; a gene mutation rate of 0.02 ; and a cross-over rate of 0.8 were used. At the end of docking, the structures were ranked by energy. Ligand-receptor interactions were all visualized on the basis of docking results using Discovery Studio Visualizer 4.0 and Ligplus2012.

\section{Conclusions}

In this study, some new monocyclic $\beta$-lactam derivatives bearing a morpholine ring substituent on the nitrogen have been synthesized and evaluated for anti-inflammatory activities. 
Some of the morpholino- $\beta$-lactam hybrids showed higher anti-inflammatory responses than the corticosteroid dexamethasone. The anti-inflammatory activity was observed to be dependent on the substituents at the $\mathrm{C} 3$ and $\mathrm{C} 4$ centers of the lactam ring. Members of the 3a-o and 5a-h series exhibit higher $\Delta \mathrm{G}_{\text {binding }}$ than the 6a-e series. The higher lipophilicity and electron-withdrawing characters had positive effect for anti-inflammatory activity and score docking. These results suggest the possibility of carrying out further studies on the mechanism of action of our compounds.

\section{Conflict of interest}

The authors declare that there is no conflict of interests.

Acknowledgments The authors thank the Shiraz University Research Council for financial support (Grant No. 98-GR-SC-23).

\section{References}

[1] K.Liaras, M.Fesatidou, A.Geronikaki, Thiazoles and Thiazolidinones as COX/LOX Inhibitors, Molecules. 23 (2018) 685. doi:10.3390/molecules23030685.

[2] L.-D. Sun, F. Wang, F. Dai, Y.-H. Wang, D. Lin, B. Zhou, Development and mechanism investigation of a new piperlongumine derivative as a potent anti-inflammatory agent, Biochem. Pharmacol. 95 (2015) 156-169. doi:10.1016/j.bcp.2015.03.014.

[3] G.S. Hassan, D.E. Abdel Rahman, E.A. Abdelmajeed, R.H. Refaey, M. Alaraby Salem, Y.M. Nissan, New pyrazole derivatives: Synthesis, anti-inflammatory activity, cycloxygenase inhibition assay and evaluation of mPGES, Eur. J. Med. Chem. 171 (2019) 332-342. doi:10.1016/j.ejmech.2019.03.052.

[4] L. Chen, H. Deng, H. Cui, J. Fang, Z. Zuo, J. Deng, Y. Li, X. Wang, L. Zhao, Inflammatory responses and inflammation-associated diseases in organs, Oncotarget. 9 (2018). doi:10.18632/oncotarget.23208.

[5] J.J. Poderoso, M.C. Carreras, C. Lisdero, N. Riobó, F. Schöpfer, A. Boveris, Nitric Oxide Inhibits Electron Transfer and Increases Superoxide Radical Production in Rat Heart Mitochondria and Submitochondrial Particles, Arch. Biochem. Biophys. 328 (1996) 85-92. doi:10.1006/abbi.1996.0146. 
[6] Y.H. Seo, J.-K. Kim, J.-G. Jun, Synthesis and biological evaluation of piperlongumine derivatives as potent anti-inflammatory agents, Bioorg. Med. Chem. Lett. 24 (2014) 57275730. doi:10.1016/j.bmcl.2014.10.054.

[7] P.D. Mehta, N.P.S. Sengar, A.K. Pathak, 2-Azetidinone - A new profile of various pharmacological activities, Eur. J. Med. Chem. 45 (2010) 5541-5560. doi:10.1016/j.ejmech.2010.09.035.

[8] L. Decuyper, M. Jukič, I. Sosič, A. Žula, M. D’hooghe, S. Gobec, Antibacterial and $\beta$ Lactamase Inhibitory Activity of Monocyclic $\beta$-Lactams, Med. Res. Rev. 38 (2018) 426503. doi:10.1002/med.21443.

[9] Y. Wang, H. Zhang, W. Huang, J. Kong, J. Zhou, B. Zhang, 2-Azetidinone derivatives: Design, synthesis and evaluation of cholesterol absorption inhibitors, Eur. J. Med. Chem. 44 (2009) 1638-1643. doi:10.1016/j.ejmech.2008.09.033.

[10] T. Dražić, V. Sachdev, C. Leopold, J. V. Patankar, M. Malnar, S. Hećimović, S. LevakFrank, I. Habuš, D. Kratky, Synthesis and evaluation of novel amide amino- $\beta$-lactam derivatives as cholesterol absorption inhibitors, Bioorg. Med. Chem. 23 (2015) 2353-2359. doi:10.1016/j.bmc.2015.03.067.

[11] E.L. Setti, D. Davis, J.W. Janc, D.A. Jeffery, H. Cheung, W. Yu, 3,4-Disubstituted azetidinones as selective inhibitors of the cysteine protease cathepsin K. Exploring P3 elements for potency and selectivity, Bioorg. Med. Chem. Lett. 15 (2005) 1529-1534. doi:10.1016/j.bmcl.2004.12.088.

[12] Y. Aoyama, M. Uenaka, M. Kii, M. Tanaka, T. Konoike, Y. Hayasaki-Kajiwara, N. Naya, M. Nakajima, Design, synthesis and pharmacological evaluation of 3-benzylazetidine-2one-based human chymase inhibitors, Bioorg. Med. Chem. 9 (2001) 3065-3075. doi:10.1016/S0968-0896(01)00209-7.

[13] B.K. Banik, I. Banik, F.F. Becker, Stereocontrolled synthesis of anticancer $\beta$-lactams via the Staudinger reaction, Bioorg. Med. Chem. 13 (2005) 3611-3622. doi:10.1016/j.bmc.2005.03.044.

[14] S. Mohammadi, S. Akbari-Birgani, M. Borji, B. Kaboudin, M. Vaezi, Diethyl [(3-phenoxy2-oxo-4-phenyl-azetidin-1-yl)-phenyl-methyl]-phosphonate as a potent anticancer agent in chemo-differentiation therapy of acute promyelocytic leukemia, Eur. J. Pharmacol. 846 (2019) 79-85. doi:10.1016/j.ejphar.2019.01.003. 
[15] M. O’Driscoll, K. Greenhalgh, A. Young, E. Turos, S. Dickey, D. V. Lim, Studies on the antifungal properties of N-thiolated $\beta$-lactams, Bioorg. Med. Chem. 16 (2008) 7832-7837. doi:10.1016/j.bmc.2008.06.035.

[16] N.B. Patel, M.D. Patel, Synthesis and evaluation of antibacterial and antifungal activities of 4-thiazolidinones and 2-azetidinones derivatives from chalcone, Med. Chem. Res. 26 (2017) 1772-1783. doi:10.1007/s00044-017-1837-6.

[17] M. Alborz, A. Jarrahpour, R. Pournejati, H.R. Karbalaei-Heidari, V. Sinou, C. Latour, J.M. Brunel, H. Sharghi, M. Aberi, E. Turos, L. Wojtas, Synthesis and biological evaluation of some novel diastereoselective benzothiazole $\beta$-lactam conjugates, Eur. J. Med. Chem. 143 (2018) 283-291. doi:10.1016/j.ejmech.2017.11.053.

[18] A. Jarrahpour, R. Heiran, V. Sinou, C. Latour, L. Djouhri Bouktab, J. Michel Brunel, J. Sheikh, T. Ben Hadda, Synthesis of New $\beta$-Lactams Bearing the Biologically Important Morpholine Ring and POM Analyses of Their Antimicrobial and Antimalarial Activities., Iran. J. Pharm. Res. $\quad$ IJPR. $18 \quad$ (2019) 34-48. http://www.ncbi.nlm.nih.gov/pubmed/31089342.

[19] T. Sperka, J. Pitlik, P. Bagossi, J. Tözsér, Beta-lactam compounds as apparently uncompetitive inhibitors of HIV-1 protease, Bioorg. Med. Chem. Lett. 15 (2005) 30863090. doi:10.1016/j.bmcl.2005.04.020.

[20] W. Wang, P. Devasthale, D. Farrelly, L. Gu, T. Harrity, M. Cap, C. Chu, L. Kunselman, N. Morgan, R. Ponticiello, R. Zebo, L. Zhang, K. Locke, J. Lippy, K. O’Malley, V. Hosagrahara, L. Zhang, P. Kadiyala, C. Chang, J. Muckelbauer, A.M. Doweyko, R. Zahler, D. Ryono, N. Hariharan, P.T.W. Cheng, Discovery of azetidinone acids as conformationally-constrained dual PPAR $\alpha / \gamma$ agonists, Bioorg. Med. Chem. Lett. 18 (2008) 1939-1944. doi:10.1016/j.bmcl.2008.01.126.

[21] A. Mermer, H. Bayrak, Y. Şirin, M. Emirik, N. Demirbaş, Synthesis of novel Azol- $\beta$-lactam derivatives starting from phenyl piperazine and investigation of their antiurease activity and antioxidant capacity comparing with their molecular docking studies, J. Mol. Struct. 1189 (2019) 279-287. doi:10.1016/j.molstruc.2019.04.039.

[22] A. Kumar, C.S. Rajput, S.K. Bhati, Synthesis of 3-[4'-(p-chlorophenyl)-thiazol-2'-yl]-2[(substituted azetidinone/thiazolidinone)-aminomethyl]-6-bromoquinazolin-4-ones as antiinflammatory agent, Bioorg. Med. Chem. 15 (2007) 3089-3096. 
doi:10.1016/j.bmc.2007.01.042.

[23] N. Borazjani, S. Sepehri, M. Behzadi, A. Jarrahpour, J.A. Rad, M. Sasanipour, M. Mohkam, Y. Ghasemi, A.R. Akbarizadeh, C. Digiorgio, J.M. Brunel, M.M. Ghanbari, G. Batta, E. Turos, Three-component synthesis of chromeno $\beta$-lactam hybrids for inflammation and

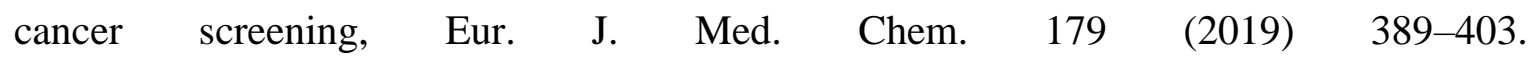
doi:10.1016/j.ejmech.2019.06.036.

[24] T.D. Nelson, J.D. Rosen, K.M.J. Brands, B. Craig, M.A. Huffman, J.M. McNamara, Syntheses of morpholine-2,3-diones and 2-hydroxymorpholin-3-ones: intermediates in the synthesis of aprepitant, Tetrahedron Lett. 45 (2004) 8917-8920. doi:10.1016/j.tetlet.2004.09.185.

[25] W. Xu, D.L. Gray, S.A. Glase, N.S. Barta, Design and synthesis of reboxetine analogs morpholine derivatives as selective norepinephrine reuptake inhibitors, Bioorg. Med. Chem. Lett. 18 (2008) 5550-5553. doi:10.1016/j.bmcl.2008.09.007.

[26] K. Audouze, E.Ø. Nielsen, D. Peters, New series of morpholine and 1,4-oxazepane derivatives as dopamine D4 receptor ligands: synthesis and 3D-QSAR model., J. Med. Chem. 47 (2004) 3089-104. doi:10.1021/jm031111m.

[27] S.A. Khanum, B.A. Begum, V. Girish, N.F. Khanum, Synthesis and Evaluation of Benzophenone-N-ethyl Morpholine Ethers as Anti-inflammatory Agents., Int. J. Biomed. Sci. 6 (2010) 60-5. http://www.ncbi.nlm.nih.gov/pubmed/23675177.

[28] B.R. Dravyakar, P.B. Khedekar, T. Khan, A.P. Sherje, K.N. Patel, V. Suvarna, Design and Development of Novel 2-(Morpholinyl)-N-substituted Phenylquinazolin-4-amines as Selective COX-II Inhibitor, Antiinflamm. Antiallergy. Agents Med. Chem. 18 (2019) 4-25. doi:10.2174/1871523017666181022144053.

[29] S. Kuettel, A. Zambon, M. Kaiser, R. Brun, L. Scapozza, R. Perozzo, Synthesis and Evaluation of Antiparasitic Activities of New 4-[5-(4-Phenoxyphenyl)-2 H -pyrazol-3yl]morpholine Derivatives, J. Med. Chem. 50 (2007) 5833-5839. doi:10.1021/jm700938n.

[30] D. Yancheva, L. Daskalova, E. Cherneva, B. Mikhova, A. Djordjevic, Z. Smelcerovic, A. Smelcerovic, Synthesis, structure and antimicrobial activity of 6-(propan-2-yl)-3-methylmorpholine-2,5-dione, J. Mol. Struct. $1016 \quad$ (2012) 147-154. doi:10.1016/j.molstruc.2012.02.057.

[31] F.R.S. Santos, J.T. Andrade, C.D.F. Sousa, J.S. Fernandes, L.F. Carmo, M.G.F. Araújo, 
J.M.S. Ferreira, J.A.F.P. Villar, Synthesis and Evaluation of the in vitro Antimicrobial Activity of Triazoles, Morpholines and Thiosemicarbazones, Med. Chem. (Los. Angeles). 15 (2019) 38-50. doi:10.2174/1573406414666180730111954.

[32] Z. Li, Z.-C. Wang, X. Li, M. Abbas, S.-Y. Wu, S.-Z. Ren, Q.-X. Liu, Y. Liu, P.-W. Chen, Y.-T. Duan, P.-C. Lv, H.-L. Zhu, Design, synthesis and evaluation of novel diaryl-1,5diazoles derivatives bearing morpholine as potent dual COX-2/5-LOX inhibitors and $\begin{array}{lllllll}\text { antitumor agents, } & \text { Eur. J. Med. Chem. } 169 & \text { (2019) 168-184. }\end{array}$ doi:10.1016/j.ejmech.2019.03.008.

[33] M.C. Chrysselis, E.A. Rekka, P.N. Kourounakis, Hypocholesterolemic and Hypolipidemic Activity of Some Novel Morpholine Derivatives with Antioxidant Activity, J. Med. Chem. 43 (2000) 609-612. doi:10.1021/jm9910391.

[34] Y. Ünver, S. Deniz, F. Çelik, Z. Akar, M. Küçük, K. Sancak, Synthesis of new 1,2,4-triazole compounds containing Schiff and Mannich bases (morpholine) with antioxidant and antimicrobial activities, J. Enzyme Inhib. Med. Chem. 31 (2016) 89-95. doi:10.1080/14756366.2016.1206088.

[35] P. Panneerselvam, R.R. Nair, G. Vijayalakshmi, E.H. Subramanian, S.K. Sridhar, Synthesis of Schiff bases of 4-(4-aminophenyl)-morpholine as potential antimicrobial agents, Eur. J. Med. Chem. 40 (2005) 225-229. doi:10.1016/j.ejmech.2004.09.003.

[36] Y.U. Cebeci, H. Bayrak, Y. Şirin, Synthesis of novel Schiff bases and azol- $\beta$-lactam derivatives starting from morpholine and thiomorpholine and investigation of their antitubercular, antiurease activity, acethylcolinesterase inhibition effect and antioxidant capacity, Bioorg. Chem. 88 (2019) 102928. doi:10.1016/j.bioorg.2019.102928.

[37] Z. Atioglu, M. Akkurt, A. Jarrahpour, R. Heiran, N. Ozdemir, 1-(Morpholin-4-yl)-4-(2nitrophenyl)-spiro[azetidine-3,90-xanthen]-2-one, Acta Crystallogr. Sect. E Struct. Reports Online. 70 (2014). doi:10.1107/S1600536814013464.

[38] A. Jarrahpour, M. Eskandari, K. Zomorodian, E. Barati, R. Ashori, M. Salehi Vaziri, K. Pakshir, Synthesis of Some New Monocyclic $\beta$-Lactams Bearing a Morpholine Moiety at their N1 Positions as Antifungal Agents, Antiinfect. Agents Med. Chem. 9 (2010) 205-219. doi:10.2174/187152110794785040.

[39] Z. Atioğlu, M. Akkurt, A. Jarrahpour, R. Heiran, N. Özdemir, 1-[3-(Morpholin-4yl)propyl]-3-[(naphthalen-2-yl)oxy]-4-(3-nitrophenyl) azetidin-2-one, Acta Crystallogr. 
Sect. E Struct. Reports Online. 70 (2014). doi:10.1107/S1600536814014949.

[40] I. Çelik, M. Akkurt, A. Jarrahpour, R. Heiran, N. Özdemir, 1-[3-(Morpholin-4-yl)propyl]4-(3-nitrophenyl)spiro[azetidine-3, 9'-xanthen]-2-one, Acta Crystallogr. Sect. E Struct. Reports Online. 70 (2014). doi:10.1107/S160053681400419X.

[41] E.U. Mughal, A. Sadiq, J. Ashraf, M.N. Zafar, S.H. Sumrra, R. Tariq, A. Mumtaz, A. Javid, B.A. Khan, A. Ali, C.O. Javed, Flavonols and 4-thioflavonols as potential acetylcholinesterase and butyrylcholinesterase inhibitors: Synthesis, structure-activity relationship and molecular docking studies, Bioorg. Chem. 91 (2019) 103124. doi:10.1016/j.bioorg.2019.103124.

[42] Y.-H. Hwang, M.-S. Kim, I.-B. Song, J.-H. Lim, B.-K. Park, H.-I. Yun, Anti-inflammatory effects of talosin A via inhibition of NF-kappaB activation in lipopolysaccharide-stimulated RAW264.7 cells, Biotechnol. Lett. 31 (2009) 789-795. doi:10.1007/s10529-009-9943-2.

[43] S. Sepehri, L. Saghaie, A. Fassihi, Anti-HIV-1 Activity Prediction of Novel Gp41 Inhibitors Using Structure-Based Virtual Screening and Molecular Dynamics Simulation, Mol. Inform. 36 (2017) 1600060. doi:10.1002/minf.201600060. 